論文

\title{
社会と原子力の関係に関する社会調查
}

\author{
篠田 佳彦 $1,2, *$, 山野 直樹2，鳥井 弘之 2
}

\section{Public Opinion Survey on the Relationship between Society and Nuclear Energy}

\author{
Yoshihiko SHINODA ${ }^{1,2, *}$, Naoki YAMANO ${ }^{2}$ and Hiroyuki TORI-I ${ }^{2}$ \\ ${ }^{1}$ Fast Breeder Reactor Research and Development Center, Japan Atomic Energy Agency, 1 Shiraki, Tsuruga-shi, Fukui 919-1279, Japan \\ ${ }^{2}$ Research Laboratory for Nuclear Reactors, Tokyo Institute of Technology, Ookayama, Meguro-ku, Tokyo 152-8550, Japan
}

(Received January 29, 2008 and accepted in revised form June 30, 2008)

The social research group of the 21st century COE program "Innovative Nuclear Energy Systems for Sustainable Development of the World" has studied under the theme coevolution of nuclear technology and society. As part of this study, this group conducted a questionnaire survey of 2,500 adults (collection rate of $22.0 \%$; 551 replies) who live in the Tokyo metropolitan area. The purpose of this survey asking opinion about the relationship between attitude toward nuclear technology utilization and social awareness is to determine their request, exception and concern about nuclear technology utilization. The survey reveals that the differences of attitudes towards nuclear technology utilization can be explained in terms of differences of general views on the society, such as the directionality of social progress. Thus, it is necessary to argue with citizens about the strategy on nuclear technology utilization from the viewpoint of the directionality of the future society. The social decision-making process on nuclear technology utilization has to be renovated through dialogue among citizens as the partner taking on the achievement and contribution toward the directionality of the future society.

\section{KEYWORDS: social science, opinion survey, social decision-making process, determinants of attitude towards nuclear technology utilization, trustworthy relation, anxiety, usefulness, directionality of future society}

\section{I.はじめに}

東京工業大学 21 世紀 COE プログラム「世界の持続的発 展を支える革新的原子力」(COE-INES)の社会研究グルー プでは, 科学技術と社会の共進化概念 ${ }^{1)}$ を提唱し, 原子力 と社会の関係改善について考究している2)。原子力は, 社 会の持続的発展のために重要な社会技術の1つである が，社会，特に一般市民に理解され，受容されているとは いい難い。その対応には，一般市民の声や意向を指針とし て技術を発展させていくことが求められる。この観点か ら, 一般市民の原子力利用 ${ }^{a}$ に対する意識や態度を調査 し，それらを知ることが久かせない。

原子力利用に対する意識調査は，これまでに多くの機関 で実施されている3)。これらの多くは表面的な意識を探る 段階に留なって抢り，原子力利用に対する態度を規定する

\footnotetext{
1 独日本原子力開発機構 高速増殖炉研究開発センター

2 東京工業大学 原子炉工学研究所

* Corresponding author, E-mail: shinoda.y.ab@m.titech.ac.jp
}

(C)Atomic Energy Society of Japan
意識の深層を解明し，そこから原子力利用の円滑推進に向 けた具体的な提言にまで踏み込んだものは少ない。また， そこで示された提言も市民に対する説明・説得の観点にお ける要点を示すに留まっている。

篠田 ${ }^{4)}$ は，これまでに実施された意識調査を分析するこ とで，一般市民の観点から原子力利用に対する態度の特徵 を論じ，原子力利用の円滑推進に向けた展開を示した。そ れを実効的なものとしていくためには，そこで見い出した 特徵を実証的データに基づいたものとしていかねばならな い。

本報は，2006年11月に実施した原子力利用に対する調 査結果ををとめ, 原子力利用に対する態度を規定する意識

\footnotetext{
a) 社会は，原子力技術を主に電力を供給する機能として活用して いる。本報では, 原子力技術を用いて電力を生み出すこと, お よび，それを実現するための施設が存在し，運転・管理されて いることを “原子力利用” という用語で捉え直す。一般市民が “(科学技術としての)原子力”をどうみているかとは, 捉え直 した“原子力利用”をどうみているかと同等と考えられる。
} 
の深層にまで踏み込んだ分析を行う。そこから, 原子力利 用々社会の関係に関わる課題を摘出し, その解決に向けた 対応について論じるものである。

\section{II. 意識調査の概要}

篠田 ${ }^{4)}$ は，原子力利用に対して消極的賛成を示す層内に 賛成的，あるいは，反対的な意識背景を有する層を想定す ることで原子力が扔かれている状況をよく説明できること を示し，その上で意識の特徴を以下と示した。

- 消極的賛成層の意識背景には, 両義性意識(賛成な 点も反対な点もあり，それが二律背反となる意識傾 向)が強く影響を及ぼしている。

- 両義性意識は, 原子力利用に対する有用一無用, 安 心-不安, 信頼一不信感情が関連しあい, 賛否に非対称 な影響を及ぼす。

・両義性意識は，原子力利用に対する「止むを得ない」 感情と結び付く。

- リスク認知に相当する安心/不安感情は, 原子力利 用を実施する主体などに対する信頼度に左右され，そ の信頼度は管理に対する期待度で規定される。

- 原子力利用に対する信頼は社会に対する信頼と結び 付 $<$ 。

- 生活を営む意識(社会意識)や価值観が原子力利用の 賛否に大きく影響を及ぼす。

上記の特徵を確認することを目指して意識調査を実施し た。まず, 原子力や社会に関連する種々の質問の回答結果 から原子力利用に対する賛否態度と種々の意識との関連を 把握し，そこから総合的な好意度を算定し，その分布を求 めた。そこから，消極的賛成層の意識は，“好意的＝賛成 的”から“非好意的＝反対的”な意識をまたいだ分布を有 することを確認し，「止むを得ない」感情の形成要因につ いて考察した。さらに，本意識調査では，原子力利用に対 する賛否の回答結果と社会意識などを含むその他質問間の 関連を探り，賛否態度の背景には成長的な経済発展志向 度，科学技術に対する期待度，および，成長的な経済発展 で生じる犠牲に対する許容度などがあることを示し，生活 意識や価值観などの影響についても検討した。以下に, 調 査実施概要を示す。

調査対象 首都圏 $40 \mathrm{~km}$ に居住する20～70歳男女

標本数 2,500 人

抽出方法 住宅地図からの無作為抽出 ${ }^{b)}$

調查時期 2006年11月 7 日～2006年12月 1 日

調査方法郵送法

b) 調査対象者の抽出において, 住民基本台帳などを閲覧すること は難しくなっている。本調査は, 住宅地図をもとに調査該当地 域から調査世帯を無作為抽出した。世帯主に回答が集中しない ように, 調査対象世帯の中で生年月日が 11 月 1 日に一番近い 同居者(世帯主を含む)を調査対象者とすることで，特定の性 別, 年代に偏りがでないように工夫した。
回収結果 有効回収数(率) 551 人 (22.0\%)

質問項目＼cjkstart原子力利用に関する質問 11 , 社会生活を営む意識などに関する質問 17

（質問文，選択肢と集計結果は付録に示 す)

\section{III. 意識調査の分析結果}

原子力利用の是非を賛否の強度を考慮して五択で尋ね た。選択肢と結果を以下に示す。

(1) 積極的に進める (6.0\%)

世強い賛成態度を示すと考えた選択肢

(2) 慎重に進める (52.1\%)

世弱い賛成態度を示すと考えた選択肢

(3) 現状を維持する (13.4\%)

(4) 少しずつ廃止する $(21.8 \%)$

世弱い反対態度を示すと考えた選択肢

(5) 全面的に廃止する (3.3\%)

Ł強い反対態度を示すと考えた選択肢

- その他 $(1.3 \%)$, 無回答 $(2.2 \%)$

提示した選択肢において, 賛成側の強度は,「積極的」と 「慎重にう消極的」と明確である。一方，「少しずつ」と 「全面的に」の文言では, 必ずしも反対の強度だけを表し ているものではなく, 廃止の現実度認識などが含まれてお り, 反対強度以外の要素が反映される点に注意を要する。 第 1 図に内閣府調查 5 ) と合わせて回答結果を示す。調査地 域や質問などが異なるが両調査とも同様な傾向を示してい る。

\section{1. 原子力利用に対する賛成態度と質問回答の関連}

原子力利用の賛否結果と他の様々な質問の回答傾向との 関連をクロス集計, 残差分析, および数量化 III 類などの 統計手法( ) を用いて探っていく。

（1）五択式賛否態度と他の質問の関連

（a）原子力利用に対する危険性認識と安心/不安 ここでは,リスク認知に相当する危険性認識と安心/不

c) 質問間のクロス集計では， $\chi^{2}$ 検定より質問間の回答の関連性 (独立性) が評価できる。さらに，残差分析を用いると選択肢ご とにどのような関連があるかを詳細にみることができる。2つ の質問の間に全く関係がない(統計的に独立な)場合の回答割合 (期待度数) との実際の回答割合の差より算出される調整済久残 差という統計量の大小によって該当項目の特異性を検定するこ とができる。

さらに数量化 III 類では, 1 人の回答者が同時に選択する傾 向が高い選択肢には近いスコアが与えられ, 関連のない選択肢 同士には遠いスコアが与えられる。回答者にも選択肢に与えら れるスコアと関連したスコアが与えられる。スコア順に配置す ると, 選択肢, 回答者になんらかの規則が視覚的に確認でき る。スコアに基づいた軸は, 選択肢と回答者をなんらかの特徵 から分類する軸 (因子) となる。因子の意味付けは分析者に委ね られている。 
安を組み合わせて質問した。集計結果は, 以下となった。

(1) 危険性を感じないので, 安心している（3.1\%)

(2) 危険性は感じるが，安心している（35.0\%)

(3) 危険性は感じないが，不安である（12.3\%）

(4) 危険性を感じるので，不安である (43.0\%)

(5) 一概にいえない $(6.0 \%)$

上記質問回答と五択賛否態度ごとのクロス集計結果を第 2 図に示す。第 2 図より安心とした選択肢(1), (2)は賛成態 度が強いほど選択割合が高く, 反対層は(1)を選んでいない

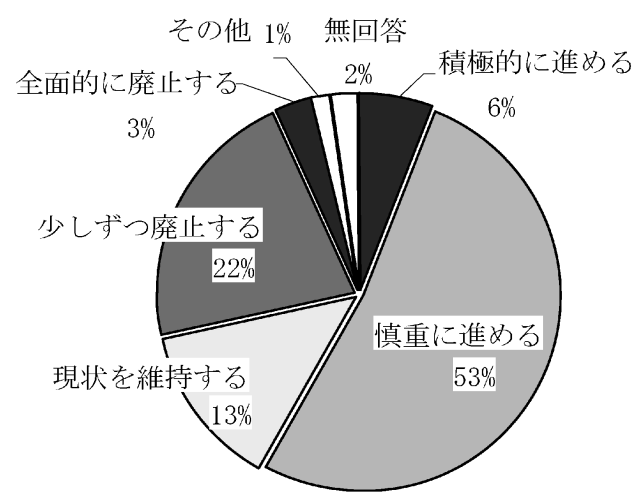

本調查（首都圈 $40 \mathrm{k} \mathrm{m}$ ）

その他 $8 \%$ 積極的に推進していく

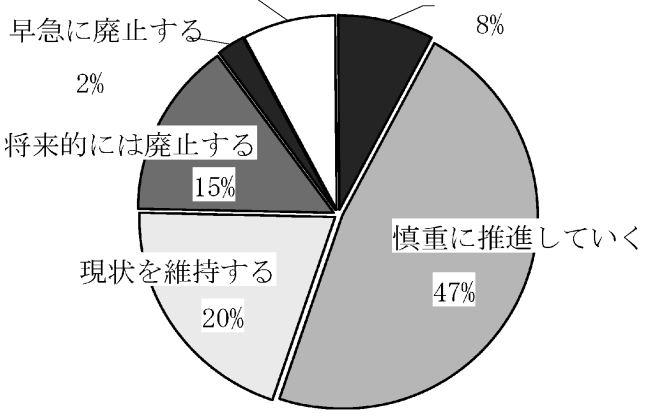

内閣府調查 ${ }^{4)}$ (全国)

第 1 図 原子力利用の是非(賛否の五択式調査)
ことがわかる。(4)は反対態度が強くなるほど選択割合が高 くなっている。残差分析では, 質問間のクロス集計におい て項目 (選択肢)ごとに有意な回答数割合の特異性について 全回答傾向を考慮して検定することができる。結果を第 1 表に示す。例えば，「積極的に進める」層は $1 \%$ の有意水 準で(1)や(2)を他の賛否層よりも高い割合で選んでいること がわかる。

数量化 III 類による分析を行うことで，回答(選択肢)の 特徵(ここでは, 選択肢を選んだ心情など)を表す因子が複 数個算出できる。危険性認識と安心 ・不安に関する回答結 果と五択賛否態度による分析から 2 つ因子を選定し， 因子ごとに選択肢のスコアを 2 組算出した。第一因子を $\mathrm{X}$ 軸に，第二因子を $\mathrm{Y}$ 軸として対応するスコアを $\mathrm{X}-\mathrm{Y}$ 平 面にプロットすることで選択肢の特徵を表す意識平面が得 られる。結果を第 3 図に示す。この平面から, 質問の回 答への関連度合い(統計的に似ている傾向の強さ)が配置の 遠近として視覚的に掴むことができる。

選定した因子は，X軸が賛成・反対を示す選択肢が強 度順に並んで抢り, 賛否傾向を示す軸(賛否軸)となるとと もに，(1)と(2)が賛成側, (3)と(4)が不安側に配置され, 安

第 1 表 クロス集計・残差分析結果

\begin{tabular}{|c|c|c|c|c|c|}
\hline 選択肢番号 & (1) & (2) & (3) & (4) & (5) \\
\hline 積極的に進める & ++ & ++ & - & -- & \\
\hline 慎重に進める & & ++ & & -- & \\
\hline \multicolumn{6}{|l|}{ 現状を維持する } \\
\hline 少しずつ廃止する & - & -- & & ++ & \\
\hline 全面的に廃止する & & -- & & ++ & \\
\hline \multicolumn{6}{|c|}{$\begin{array}{l}\text { 該当部分の回答割合が, } \\
++1 \% \text { 有意水準で高い } \\
\quad+5 \% \text { 有意水準で高い } \\
-\quad-1 \% \text { 有意水準で低い } \\
\quad-5 \% \text { 有意水準で低い } \\
\text { 灰色空白欄は(有意ではないが)低い } \\
\text { 空白欄は (有意ではないが)高い。 }\end{array}$} \\
\hline
\end{tabular}

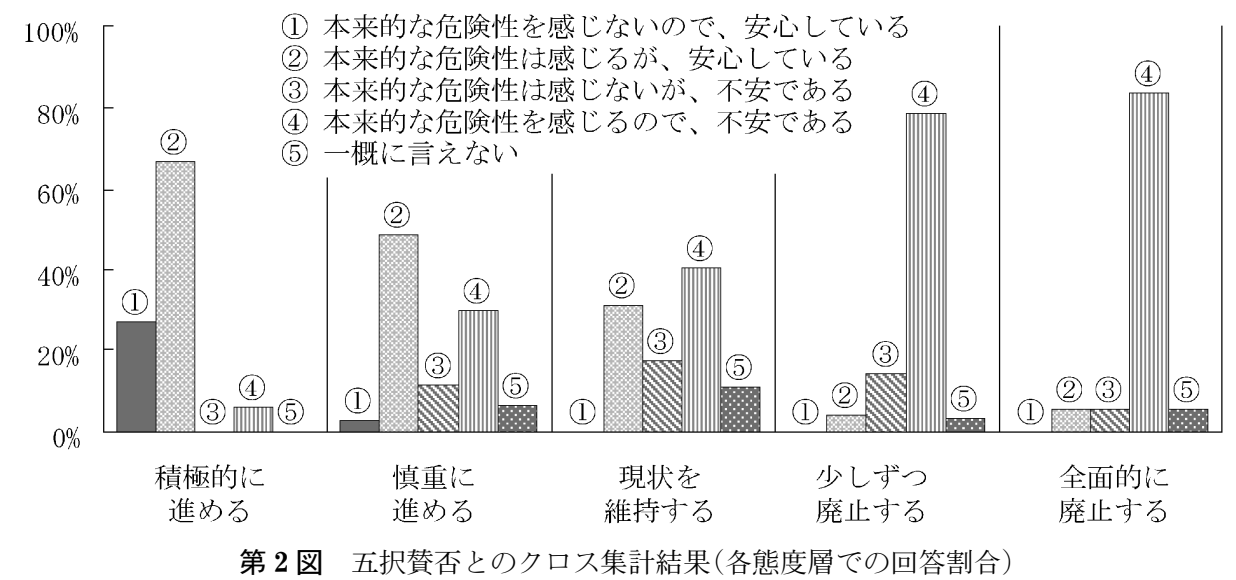


(1)

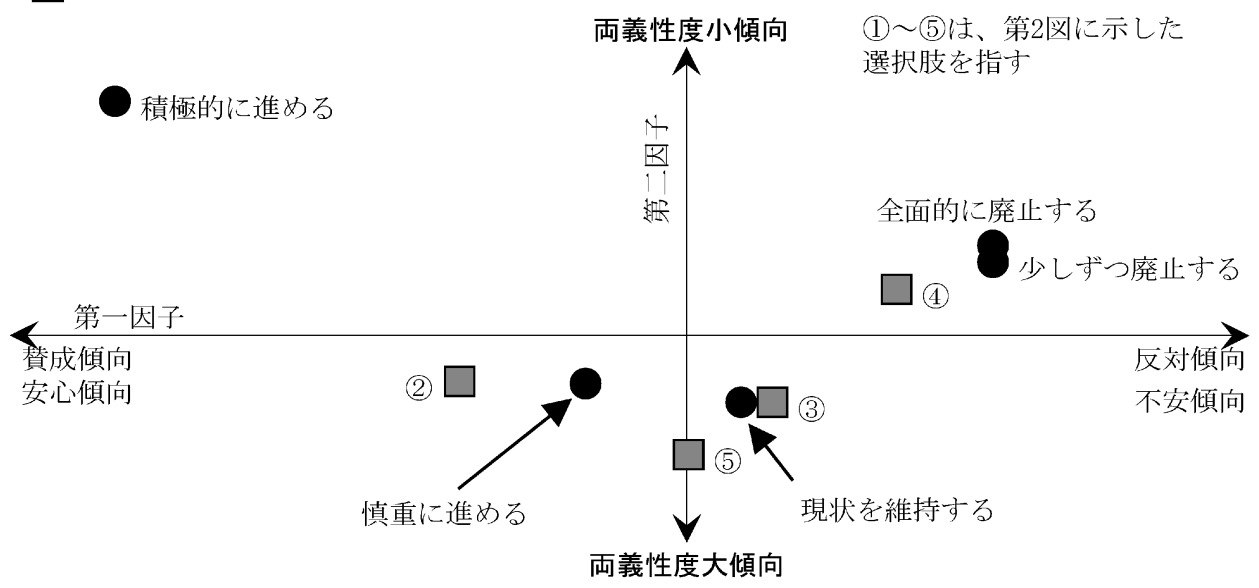

第 3 図 五択賛否と「危険性認識と安心 · 不安」の質問間に抢ける数量化 III 類分析結果

心ー不安を示す軸にもなっている。ここでの質問では, 安 心/不安は有無を尋ね, その度合い(強度)は尋ねていな い。しかし，この分析から第一因子のスコアが，安心/不 安の強度に相当するものであることもわかる。これより， 賛成強度には安心の強度が影響するが，「全面的に廃止す る」と「少しずつ廃止する」で第一因子のスコアの差がな く，これらの選択肢を選んだ層の反対強度に安心一不安の 観点の影響が少ないことがわかる。

分布は，「現状を維持する」を底にしたり型であり，Y 軸は主張の強さを示している。 $\mathrm{Y}$ 軸の上側は「危険性を 感じないので安心」,「感じるので不安」とする見解であり, 下側が「感じるが安心」，「感じないが不安」である。これ は，「ので」(順接）と「が」(逆説)で結び付けられた意識 構造の特徵を示す軸である。さらに，6\%が選択している 「(5)一概にいえない」が Y 軸の最下部にあり，明確な回答 を避ける意識を合わせた両義性傾向の強弱を示す軸となっ ていると考えられる。以下，同様な分析を質問ごとに行っ た。

（b）興味・関心，および自分への関わり意識

原子力利用に対する興味・関心と自分への関わり意識の 有無を同時に尋ねた。回答者の $53.9 \%$ が興味・関心，およ び自分への関わり意識がともにあると回答している。この 質問と五択賛否態度を組み合わせて数量化 III 類で分析す ると，選択肢スコアの配置から第一因子として興味・関心 の有無を示す軸が，第二因子として自分への関わりの有無 を示す軸が現れ，興味・関心と関わりの有無を示す意識平 面を得る。

この意識平面において，「積極的に進める」層は興味・ 関心，自分への関わりがともにありとする象限に位置し， この層は興味・関心抢よび自分への関わり意識がともにあ るとする傾向をもつことがわかる。同様に，「全面的に廃 止する」と「慎重に進める」層は興味・関心はあるが，自 分への関わりがなく，「少しずつ廃止する」層は興味・関
心はないが，自分への関わりはあり，「現状を維持する」 層は興味・関心も自分への関わりがともにないとする傾向 を見い出すことができる。なお，興味・関心や自分への関 わり意識と賛否態度は連関せず，賛否軸は表れない。

(c) 原子力利用の必要性認識(現在と将来に打ける必要 性)

現在と将来の 2 つの時点での必要性について尋ねた。 将来として，どの時期を想定するかは，回答者の判断に委 ねた。集計結果は，以下となった。

(1) 今も役立っているし，将来も必要である $\%)$

(2) 今は役立っているが，将来は必ずしも必要ではな い $(28.7 \%)$

(3) 今は役立っているが，将来は不要である $\%)$

(4) 今は役立っていないが，将来は必要である $\%)$

(5) 今は役立っていないが，将来は必要になる場合も ある (1.1\%)

(6) 今も役立っていないし，将来も不要である（0.4 $\%)$

(7) 一概にいえない $(6.0 \%)$

回答者の $89.1 \%$ が現時点の必要性を認識している。将来 に抢ける必要性は，必要 $53.6 \%$, 不要 $8.7 \%$, 状況による $29.8 \%$ と見解が分かれている。

五択賛否態度と必要性認識を数量化 III 類によって分析 すると，第一因子は賛否強度を示すとともに賛成側から 「将来は必要」,「状況による」,「不要」の順に選択肢が並 ぶ。将来的に不要になるとみている層が反対する傾向を示 し，将来の必要性に対する認識は賛否を分けることを掴め る。一方，五択賛否選択肢の配置は $\vee$ 型とならず，第二因 子は両義性を示さない。

（d）原子力利用を行っていることへの信頼感と判断根 
拠

原子力利用全般への(ある意味で漠然とした)信頼につい て強度(信頼度合い)を考慮して四択で尋ねた。集計結果 は，以下となった。

(1) 信頼している (9.8\%)

(2) まあ信頼している (47.4\%)

(3) あまり信頼していない（26\%）

(4) 信頼していない (8.9\%)

五択賛否態度と合わせた数量化 III 類による分析では, 第一因子が賛否度と同時に信頼度を示す軸になる。強度を 考慮した賛否態度と信頼度が強く連関している。第二因子 は「現状を維持する」を底にしたマ型であり，信頼度合い を示す選択肢(1)～(4)も V型の配置となる。中間回答を好む 傾向を示すとともに両義性の度合いを示しているものとみ ることができる。

中間回答が，控えめ表現なのか，意識の葛藤なのかを区 別することは簡単ではない。第二因子は両義性の度合いを 示すものと捉えるが，そこには，強い主張や断定を避ける 気質も含まれている。中間回答をさせる要因として, 両義 性意識の存在と断定を避ける気質が複合したものと捉える ことが妥当であろう。

さらに, 信頼度を判断した観点について, 技術的観点, 組織の姿勢などの選択肢を提示し，複数選択式で尋ねた。 選択肢の詳細は，付録を参照されたい。五択賛否との間で のクロス集計と残差分析から，以下が特徵的となる。

-「積極的に進める」層は技術的観点を選択する割合 が78.8\% (全回答者では $44.3 \%$ ) であり，1\%の有意水 準で他層より回答割合が高い。一方, 原子力関係者が 原子力利用に取り組む姿勢 $(3.0 \%$ ，全回答者では 24.0 \%)を選択する割合が有意に低い。

・「慎重に進める」層は, これまでの実績 $(54.7 \%$, 全 回答者で $49.7 \%)$ が有意に高い。

・「少しずつ廃止する」層は,これまでの実績 $(41.7$ $\%$, 全回答者では $49.7 \%)$ が有意に低く, 国の安全規 制に対する取り組み $(53.3 \%$ ，全回答では $43.9 \%)$ が有 意に高い。

-「全面的に廃止する」層は原子力利用に取り組む姿 勢(44.4\%，全回答者では24.0\%)が有意に高い。

さらに選択肢として「信頼するしかない」を盛り込んだ。 信頼度を判断する観点としては奇異であるが，全回答者の $22.7 \%$ が選んでいる。「慎重に進める」,「現状を維持する」 層はそれぞれ $25.8 \% ， 29.7 \%$ と高い割合で選択している。 一方で「少しずつ廃止する」層と「全面的に廃止する」層 は， $14.2 \% ， 5.6 \%$ と回答割合が低く, 賛成層ほど「信頼 するしかない」意識を抱いていることがわかる。

また, 原子力への信頼, 信頼を判断する観点, および原 子力利用に対する本来的危険性認識と安心/不安の質問間 で数量化 III 類による分析を行うと第一因子に信頼一不信, 安心-不安を示す軸が現れる。(信頼, 安心)-(不信, 不安)
傾向と強度が連関している。さらに第一因子のスコアから 信頼を判断する観点として,「技術的観点」,「これまでの 実績」,「専門家の意見」,「社会の雾囲気」,「信頼するしか ない」の観点が信頼者の判断根拠となっている傾向が掴め る。特に，「信頼するしかない」は，「まあ信頼している」 とほぼ同值のスコアを有し，「まあ信頼している」を選ん だ回答者の判断根拠が，「信頼するしかない」とする傾向 が他の信頼強度層(特に不信層)よりも強いことがわかる。 一方，不信層は，国や原子力に関係している組織や人の姿 勢や取り組みなどを根拠としていることも読及取れる。

（e）原子力利用がもたらす恩恵と犠牲

原子力利用がどのような恩恵と儀牲をもたらすかについ て，それぞれ10個の選択肢を提示して複数回答可で尋ね た。何を選択したかとともに何個選択したかも重要な観点 となる。選択個数と五択賛否態度の間で残差分析をすると 第 2 表を得る。第 2 表中の選択割合が有意に高い(あるい

第 2 表 クロス集計・残差分析結果

（1）恩恵選択個数と五択賛否

\begin{tabular}{|c|c|c|c|c|c|}
\hline $\begin{array}{l}\text { 恩恵選 } \\
\text { 択個数 }\end{array}$ & $\begin{array}{l}\text { 積極的に } \\
\text { 進める }\end{array}$ & 慎重に進 & $\begin{array}{l}\text { 現状を維 } \\
\text { 持する }\end{array}$ & $\begin{array}{l}\text { 少しずつ } \\
\text { 廃止する }\end{array}$ & $\begin{array}{l}\text { 全面的に } \\
\text { 廃止する }\end{array}$ \\
\hline 0 個 & & -- & & & ++ \\
\hline 1 個 & & - & & ++ & \\
\hline \multicolumn{6}{|l|}{2 個 } \\
\hline \multicolumn{6}{|l|}{3 個 } \\
\hline 4 個 & & ++ & & -- & \\
\hline 5 個 & & & -- & & \\
\hline 6 個 & ++ & & & & \\
\hline 7 個 & + & & & & \\
\hline 8 個 & ++ & & & & \\
\hline \multicolumn{6}{|l|}{9 個 } \\
\hline 10個 & ++ & & & & \\
\hline
\end{tabular}

（2）犠牲選択個数と五択賛否

\begin{tabular}{|c|c|c|c|c|c|}
\hline $\begin{array}{l}\text { 犠牲選 } \\
\text { 択個数 }\end{array}$ & $\begin{array}{l}\text { 積極的に } \\
\text { 進める }\end{array}$ & 慎重に進 & $\begin{array}{l}\text { 現状を維 } \\
\text { 持する }\end{array}$ & $\begin{array}{l}\text { 少しずつ } \\
\text { 廃止する }\end{array}$ & $\begin{array}{l}\text { 全面的に } \\
\text { 廃止する }\end{array}$ \\
\hline 0 個 & ++ & & & - & \\
\hline 1 個 & ++ & & & -- & \\
\hline 2 個 & & + & & & - \\
\hline \multicolumn{6}{|l|}{3 個 } \\
\hline 4 個 & - & & & & \\
\hline 5 個 & & - & & ++ & ++ \\
\hline 6 個 & & & & ++ & \\
\hline \multicolumn{6}{|l|}{7 個 } \\
\hline \multicolumn{6}{|l|}{8 個 } \\
\hline 9 個 & & & & & ++ \\
\hline
\end{tabular}

表中の記号は第 1 表と同様。 
は低い)項目の分布より，恩恵選択個数は賛成層で多く, 反対層で少ないこと, 犠牲選択個数は賛成層で少なく, 反 対層で多いことが読み取れる。賛成層は恩恵を，反対層は 犠牲を強く意識していることが国め, 賛成・反対とも賛否 態度が強くなるとどちらか一面を強く意識するようにな る。これから, 藤井ら ${ }^{6}$ )が指摘したフレーミング効果 $($ 自 身の態度によって, 恩恵か犠牲のどちらか一面を強く意識 するようになること)が確認された。

（f）将来社会に対する考え方(成長と犠牲のイメージ)

これからの社会に対する考え方を尋ねた。回答割合と結 果を第 4 図に示す。「成長を望んでいない」，あるいは， 「無理してまで望まない」とする回答も多い。五択賛否態 度とのクロス集計結果を第 4 図(1)に示す。残差分析より 賛否に強く影響している意識であり，賛成層と反対層とも それぞれの層内での賛否強度にも影響していることがわか
る。そして，以下の傾向を読み取ることができる。

・成長を志向する(1)は,「積極的に進める」層の選択 割合が高く，賛成態度が弱まるほど低くなる。

・「全面的に廃止する」層は, (1)と(3)を選んでいない。

- 5は「全面的に廃止する」層の割合が高く, 反対強 度が弱まるほど低くなっている。

五択賛否態度との数量化 III 類による分析では, 第 4 図 (2)に示す賛否軸が現れる。同時に, 成長のための犠牲を 許容するか否かを示す軸にもなっており, 賛成層は犠牲を 許容する傾向をもち, 反対層は犠牲を拒否する傾向をもつ ことがわかる。分布は、型であり，Y 軸は下方向ほど現 状維持を志向している選択肢が配置され, 上方向は現状改 革を志向する選択肢が配置されており，両義性の度合いを 示すとともに現状に対する認識を示す軸が現れる。

将来社会に関する質問の選択肢では, “犠牲”とだけ提

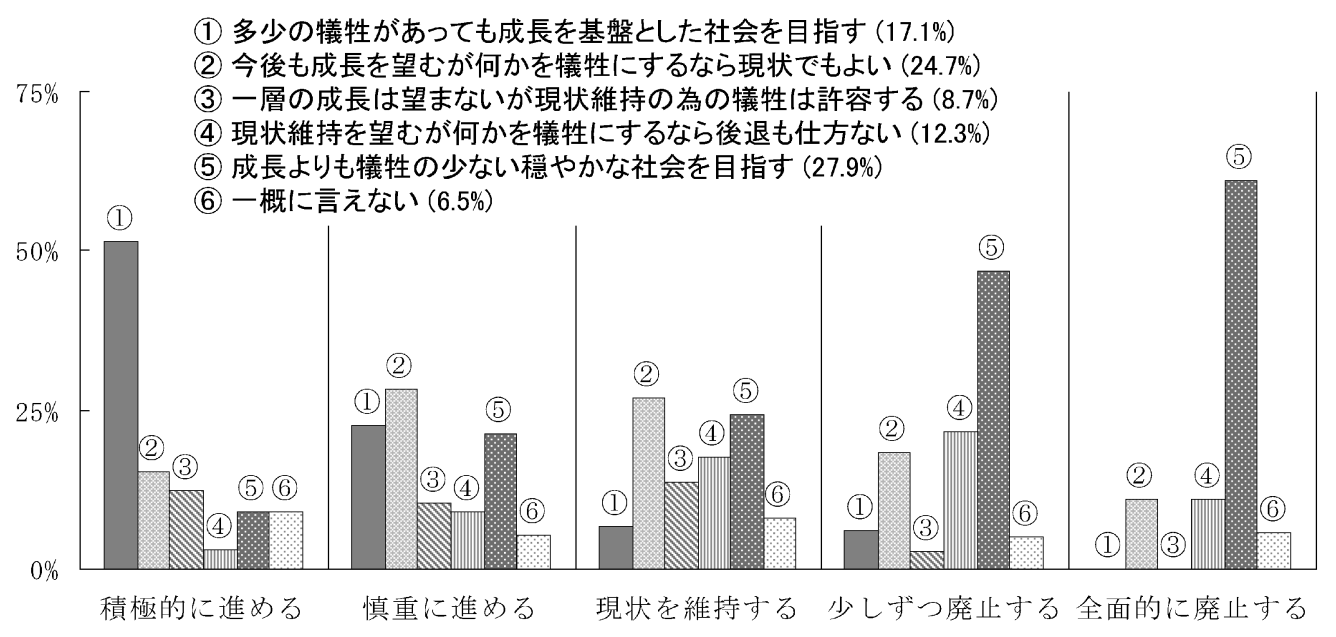

(1) クロス集計

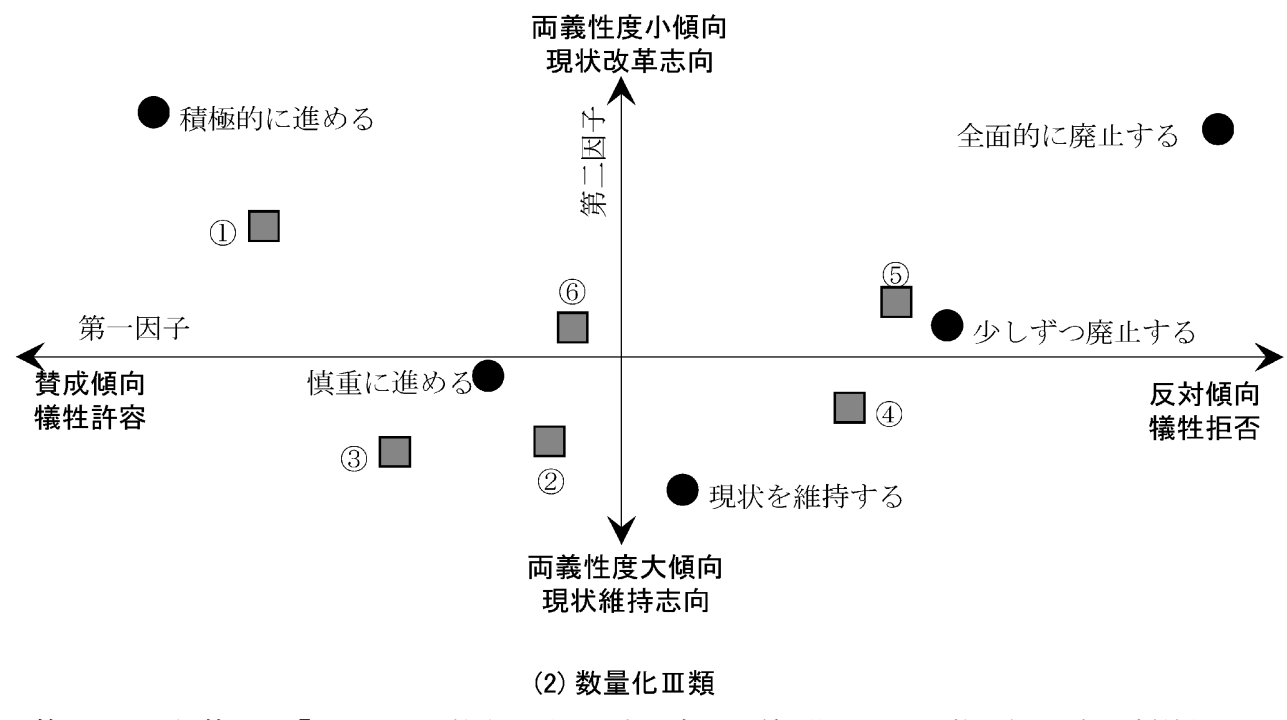

第 4 図 五択賛否と「これからの社会に対する考え方」の質問間における数量化 III 類分析結果 
示し, その具体的内容を示さなかった。この質問の後で “犠牲”のイメージを「自然環境」,「文化」,「人間性」, 「暮らしやすさ」, 「平和」, 「物質的豊かさ」, 「精神的豊か さ」,「ゆとり」などを選択肢として複数選択式で尋ねた。 原子力利用に対する賛否感情で求めるもの（犠牲＝失いた くないもの)が変わる。残差分析から, 賛成層と反対層の 犠牲に対する捉え方が大きく異なることが，(e)で示した 原子力利用がもたらす犠牲を尋ねた質問と同様にこの質問 でも現れる。賛成層はどの選択肢も選択割合が低く, 選択 個数が少ない。一方, 反対層はほとんどの選択肢で選択割 合が高く，選択個数が多くなっている。

選択肢内容による特徵は反対強度に顕著に現れる。「少 しずつ廃止する」層は「物質的豊かさ」の久他層より選択 割合が低く，他の選択肢の選択割合は高い。特に，「平和」 を重視するとともに「精神的豊かさ」を基調とした暮らし やすい社会を望んでいる傾向がある。一方，「全面的に廃 止する」層は, 必ずしも「物質的豊かさ」を否定していな w。

なお，これらの質問の前に原子力利用の犠牲について尋 ねており, 回答者は犠牲の観点として, 将来社会に求める ものと原子力利用による犠牲を結び付けること（すなわ ち，質問文や質問順序によって“刷り込み”を受けること） が考えられる。原子力利用がもたらす犠牲と将来社会の動 向における犠牲の間で残差分析を行った。回答割合が有意 に異なるものとして, 成長を強く志向している層（選択肢 (1)を選んだ層)の36.2\% (全回答者では56.6\%)が，原子力 利用がもたらす犠牲として「生活環境や自然環境への被害」 を選択し，その回答割合は他の層に比べて有意に低い。そ の他に有意な回答割合の差異はない。「積極的に進める」 層は(1)を選択する割合が有意に高く,この層の久が成長的 社会を念頭として，すなわち原子力利用がもたらす恩恵と して,「便利で安定な生活」,「経済発展」を有意に高い割 合で選択し，原子力利用と将来社会を強く結び付けている ことが掴める。

（g）科学技術への期待と導入によって生じる損失への 対応

まず，科学技術への期待を地球温暖化や環境問題の解決 への意識を通して調査した。その対策として科学技術の進 歩を選択する割合は，「現状を維持する」層が $43.2 \%$ (全回 答者では $61.3 \%)$ と最も低く, 逆に「積極的に進める」層 は $84.8 \%$ が選択している。「積極的に進める」層は, 多少 の犠牲を伴っても経済成長を望み, 経済成長に伴う環境へ の負荷緩和を科学技術の進歩に求めて抢り，自身の生活を 改めるとする意識は他の層よりも低い。一方, この層は環 境問題の解決に向けて, 自身の生活变化を厭わず（回答に 矛盾がある)，社会貢献に対しても積極的な意識を有する など社会志向を示している。賛成/反对を含め賛否態度が 強い層ほど, 問題解決に向けた生活変化への対応に積極的 な姿勢を有している。
科学技術の導入によって生じる危険性への対応に対する 意識において，危険性に対する許容度や自己責任意識(危 険性の回避への依存傾向, 制御可能性認識を伴う)の強弱 と賛否態度が連関している。

（h）社会をリードしている組織や人々に対する信頼感 社会をリードしている組織や人々dに対する信頼感につ いて強度を考慮して四択で尋ねた。結果は以下となった。
(1) 信頼している (3.1\%)
(2) まあ信頼している (26.9\%)
(3) あまり信頼していない $(44.5 \%)$
(4) 信頼していない $(14.7 \%)$
(5) 一概にいえない $(8.7 \%)$

原子力利用に対する賛否態度と信頼の連関は原子力への 信頼も社会への信頼も同様な傾向をみせる。残差分析の結 果を第 3 表に示す。選択割合が有意に高い項目（あるいは 少ない)が対角に並んでおり，連関が強いことがわかる。 賛否態度と社会への信頼度が連関している(相関係数 $0.370, \mathrm{p}=7.84 \mathrm{e}-17$ )。なお, 賛否態度と原子力への信頼 度は, 相関係数 0.611 とより強く関連している。賛成層は 社会も原子力も信頼し, 逆に反対層は社会も原子力も信頼 していない傾向がみて取れる。現状維持を志向する層は, 原子力はある程度は信頼しているが，社会をあまり信頼し ていない傾向がある。

この後で，社会をリードしている組織やその中の人々と して何を連想するかを複数選択式で尋ねた。「積極的に進 める」層は, 学者や専門家を選ぶ割合が $42.4 \%$ (全回答者 では $37.2 \%$ ) と高く，彼らへの信頼感が高いことがわか る。賛成層ほど科学技術への期待度などが高いこととも整 合が取れている。科学技術への期待度とそれを実行してい る学者や専門家への信頼度が高いことがこの層の特徵とい える。

一方，「少しずつ廃止する」と「全面的に廃止する」層 は，大企業・産業界をそれぞれ55\%，50\%（全回答者では

第 3 表 クロス集計・残差分析結果

\begin{tabular}{|c|c|c|c|c|c|}
\hline 選択肢番号 & (1) & (2) & (3) & (4) & (5) \\
\hline 積極的に進める & ++ & ++ & - & - & \\
\hline 慎重に進める & & ++ & - & -- & \\
\hline 現状を維持する & & - & & & \\
\hline 少しずつ廃止する & & -- & ++ & + & \\
\hline 全面的に廃止する & & -- & & ++ & \\
\hline
\end{tabular}

表中の記号は第 1 表と同様。

d) 社会のあり方や方向性を先導し，そのために社会を機能させて いる制度や仕組みを決め, 同時にそれを司る組織やその中で活 動する者を網羅した概念であり, 人々の生活を左右する機能体 を指す。そして，人々が自身の生活を左右しているものと認識 しているものでもある。 
46.5\%) と回答割合が高い。これらの層は犠牲に敏感に反 応する傾向がみて取れる。そこから，犠牲に目を向けない 利益優先主義に不信感をもつこの層が利益優先主義とみて いる大企業 · 産業界に理念 · 価值観の不一致として不信感 を抱いているものと推測できる。

(i) 価值観などの影響

生活目標や理想の家族像, 人間像などを通して, 生活意 識や価值観を調査した。価值観とは善悪・好悪に対する判 断基準であり，物事に向き合う態度は価值観に規定され， 価值観と矛盾しないように形成される7)。将来社会として 望むイメージや原子力利用による恩恵や犠牲などは, 価值 観が直接的に反映されやすいものと考えられる。

生活目標 (生活していくための視点) として, 個人的一社 会的欲求と短期的-計画的志向のどれを重視するかを組み 合わせて尋ねた。この質問では，NHK 放送文化研究所8) が継続的に実施している意識調査を参考とし，生活目標を 文言で尋ねた。選択肢は付録に示すが，欲求・志向を直接 的に尋ねたものではなく, 文言の意味から回答者の欲求 · 志向を推定するものとした。なお，ここで用いた選択肢で は，個人的欲求は自己の生活を中心的に満足させること を，社会的欲求は自己以外の他者にも目が向いていること を指し, 計画的志向は将来にも目が向いていることを, 短 期的志向は主に現時点のみに目線が集中していることを示 している。

五択賛否態度と生活目標を合わせて数量化 III 類によっ て分析すると,「積極的進める」層は個人+計画的, 「慎重 に進める」，「現状を維持する」層は個人十短期的，「少し ずつ廃止する」層は社会十短期的，「全面的に廃止する」 層が社会＋計画的志向を有する傾向があることが示され る。弱い賛否層の視点は現在にあり, 将来的な視点をもつ 傾向が低い。「積極的に進める」層と「全面的に廃止する」 層は, 計画的な生活目標を有し, 将来に目が向いている。 個人的欲求か社会的欲求のどちらを有するかが，賛否を分 け，将来的か短期的な視点が，同一賛否層内の強度を分け る要因となる。ただし，社会貢献意識を尋ねた質問では， 「積極的に進める」層は積極的な社会志向を直接示した選 択肢を多く選んで抢り，生活目標志向と合致しない。これ は，意識は必ずしも整合が取れている訳ではないことによ る回答の矛盾か，あるいは，直接的な選択肢による表層的 心理と文言の意味に含まれた深層的心理の差違によるもの と思われる。「積極的に進める」層は，自身がこうすべき とする意識が，他者も自身と同様にこうあるべきとする意 識に転化している傾向を感じさせ，個人的欲求からの集団 重視志向の存在を意識させる。

また，伝統志向の尺度にもなる「理想とする家族 ·夫婦 関係」を尋ねた。家族関係に対する伝統的一近代的志向の 強弱と賛否態度が連関した。伝統志向の強弱は，社会を リードする対象や社会的意思決定に対する意識などに影響 を及ぼす。恩恵・犠牲に対する見方，信頼度の判断の仕
方, 将来社会のイメージなどは, 生き方を示しているこれ らの意識によって影響されていることが確認できた。

\section{（2）原子力利用に対する消極的賛成層の意識背景の分} 離

五択選択肢で尋ねた賛否とその他の質問との関連性を探 ることで，消極的賛成層の意識背景を分析することができ る。原子力に関わる意識の中で「Q4. 原子力利用の有用 性 (現在と将来に抢ける必要性)」,「Q5. 原子力利用に対 する危険性認識と安心 ・不安」, 「Q6. 原子力利用を行っ ていることへの信頼性」, 社会意識の中で「Q16. これか らの社会に対する考え方」，「Q20. 科学技術の導入によっ て生じる損失や危険性への対応」,「Q22. 社会をリードし ている組織や人々に対する信頼度」を尋ねた質問に賛否強 度と強い連関があり，それらの回答を用いた数量化 III 類 による分析によって賛否軸が表れた。これらの回答から， 賛否回答だけでは表せない原子力に対する総合的好意度を 定量的に評価できる。ここでは，各選択肢のスコアを 2 つの因子について算出した。各質問の選択肢ごとのスコア は第 4 表抢よび第 5 図に示す。

第 5 図は $\vee$ 型に分布しており，X 軸は賛否度， $\mathrm{Y}$ 軸は 両義性度を示している。回答者がどの選択肢を選んだかに よって, 質問ごとに賛否度と両義性度が決まる。回答者 は，ここで示した質問について様々な組み合わせで回答す る。各選択肢に与えられたスコアに基づき, 回答者にも選 んだ選択肢に対応した評点が付く。その值を全質問で足し 合わせると，回答者ごとに複数の質問を総合した賛否度と 両義性度を算出することができる。第 6 図に全回答者の 総合的態度を示す。図中の各点は, 回答者個々の総合的賛 否度と両義性度で配置されている。なお, 平面の原点は, その軸で示される傾向の中間点となり，特性を分けている。

第 6 図に示した各回答者の原子力利用に対する総合的 態度は, 五択賛否態度で特徵付けることができる。第 7 図では, 第 6 図を五択賛否態度ごとに分離して表示す る。それぞれの層が “広がり”をもち，分布に他の賛否層 と重なる部分が存在している。「積極的に進める」層と 「全面的に廃止する」層(強い態度層)の賛否度は, 回答し た賛否と同一範囲に分布し，賛否をまたいでいない。同時 に，両義性の意識度合いも低い。一方，「慎重に進める」 層は，賛否軸において，反対度をもつ範囲まで回答者が分 布している。賛成側の分布は，「積極的に進める」層と重 複している。「積極的に進める」層より両義性度が高いこ とがわかる。「慎重に進める」層は賛否をまたいでおり， 意識の背景としての賛否度を考慮して，それぞれ「慎重に 進める一賛成的」および「慎重に進める一反対的」層に分け ることができる。本調査では，「慎重に進める一反対的」層 は回答者全体の $20 \%$ 程度となっている。これは，「慎重に 進める」を選択した弱い賛成層の特徽である。また，「少 しずつ廃止する」層は，「全面的に廃止する」層より，中 間よりの反対域に分布している。こちらも，「全面的に廃 
第 4 表 各質問の選択肢ごとのスコア

\begin{tabular}{|c|c|c|c|}
\hline 質問 & 選 択 肢 & 第 1 因子 & 第 2 因子 \\
\hline \multirow{5}{*}{ 賛否 } & (1)積極的に進める & -2.60 & 3.52 \\
\hline & (2)慎重に進める & -0.65 & -0.66 \\
\hline & (3)現状を維持する & 0.27 & -1.12 \\
\hline & (4)少しずつ廃止する & 1.62 & 1.01 \\
\hline & (5)全面的に廃止する & 2.66 & 2.88 \\
\hline \multirow{7}{*}{ Q4 } & $\begin{array}{l}\text { (1) 今も役立っているし, 将来も } \\
\text { 必要であ }\end{array}$ & -1.01 & -0.27 \\
\hline & $\begin{array}{l}\text { (2)今は役立っているが，将来は } \\
\text { 必ずしも必要ではない }\end{array}$ & 0.98 & 0.07 \\
\hline & $\begin{array}{l}\text { (3) 今は役立っているが, 将来は } \\
\text { 不要である }\end{array}$ & 1.80 & 2.13 \\
\hline & $\begin{array}{l}\text { (4)今は役立っていないが, 将来 } \\
\text { は必要である }\end{array}$ & -0.77 & -1.45 \\
\hline & $\begin{array}{l}\text { (5)今は役立っていないが，将来 } \\
\text { は必要になる場合もある }\end{array}$ & 1.47 & 0.56 \\
\hline & $\begin{array}{l}\text { (6) 今も役立っていないし, 将来 } \\
\text { も不要である }\end{array}$ & 2.10 & 2.12 \\
\hline & (7)一概に言えない & 1.27 & -0.73 \\
\hline \multirow{5}{*}{ Q5 } & $\begin{array}{l}\text { (1)本来的な危険性を感じないの } \\
\text { で, 安心している }\end{array}$ & -3.10 & 5.70 \\
\hline & $\begin{array}{l}\text { (2)本来的な危険性は感じるが， } \\
\text { 安心ている }\end{array}$ & -1.23 & -0.43 \\
\hline & $\begin{array}{c}\text { (3)本来的な危険性は感じない } \\
\text { が，不安である }\end{array}$ & 0.19 & -1.13 \\
\hline & $\begin{array}{l}\text { (4)本来的な危険性を感じるの } \\
\text { で, 不安である }\end{array}$ & 1.11 & 0.55 \\
\hline & (5)一概に言えない & 0.55 & -1.67 \\
\hline \multirow{5}{*}{ Q6 } & (1)信頼している & -2.42 & 3.28 \\
\hline & (2)まあ信頼している & -0.67 & -1.08 \\
\hline & (3)あまり信頼していない & 1.19 & 0.33 \\
\hline & (4)信頼していない & 2.23 & 2.30 \\
\hline & (5)一概に言えない & 0.72 & -1.06 \\
\hline \multirow{6}{*}{ Q16 } & $\begin{array}{c}\text { (1)多少の犠牲があっても成長を } \\
\text { 基盤とした社会を目指す }\end{array}$ & -1.39 & 0.93 \\
\hline & $\begin{array}{c}\text { (2)今後も成長を望むが何かを犠 } \\
\text { 牲にするなら現でもよい }\end{array}$ & -0.14 & -0.40 \\
\hline & $\begin{array}{c}\text { (3)一層の成長は望まないが現状 } \\
\text { 維持の為の犠牲は許容する }\end{array}$ & -1.05 & -1.00 \\
\hline & $\begin{array}{c}\text { (4)現状維持を望むが何かを犠牲 } \\
\text { にするら後退も仕方ない }\end{array}$ & 0.73 & 0.01 \\
\hline & $\begin{array}{l}\text { (5)成長よりも犠牲の少ない穏や } \\
\text { かな社会を目指す }\end{array}$ & 0.90 & 0.21 \\
\hline & (6一概に言えない & 0.50 & -0.16 \\
\hline \multirow{7}{*}{ Q20 } & $\begin{array}{l}\text { (1)国や地方自治体がしっかり規 } \\
\text { 制すべきだ }\end{array}$ & 0.07 & 0.32 \\
\hline & 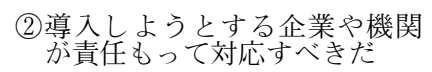 & -0.33 & -1.14 \\
\hline & $\begin{array}{l}\text { (3)個人個人が自己責任で対応す } \\
\text { べきだ }\end{array}$ & -1.29 & 1.62 \\
\hline & $\begin{array}{c}\text { (4)損失や危険性を最小限に抑え } \\
\text { る事を導入の前提とすべき }\end{array}$ & -0.21 & -0.52 \\
\hline & $\begin{array}{c}\text { (5)損失や危険性がまったく無い } \\
\text { ととを導入の条件とすべき }\end{array}$ & 0.62 & 0.13 \\
\hline & $\begin{array}{c}\text { (6)ある程度の利益があれば損失 } \\
\text { や危険性はやむをな }\end{array}$ & -1.17 & 1.11 \\
\hline & (7)一概に言えない & 0.74 & -0.48 \\
\hline \multirow{5}{*}{ Q22 } & (1)信頼している & -2.46 & 4.25 \\
\hline & (2)まあ信頼している & -1.16 & -0.16 \\
\hline & (3)あまり信頼していない & 0.31 & -0.34 \\
\hline & (4)信頼していない & 1.38 & 0.68 \\
\hline & (5)一概に言えない & 0.65 & -0.68 \\
\hline
\end{tabular}

止する」層よりも両義性度が高い。この層には，賛否と意 識の背景が異なる層(「弱い反対一賛成的」層) は存在しな い。さらに,「現状を維持する」層は, 高い両義性と中間 点の周りの賛否両域に分布している。

この分析により，弱い賛成を示す選択肢を選んだ層 $(=$ 「慎重に進める」層)の意識には有用性認識と不安に代表さ れる両義性意識が存在し, 意識の背景において賛成的か反 対的な色彩を有する層に分けられることが確認できた。意 識の背景は, 両義性意識のバランスによるものとなる。

\section{2. 原子力利用に対する賛否回答とその背景}

原子力利用の賛否態度に原子力の有用一無用, 安心-不 安, 信頼一不信の因子が大きく影響していることは, これ までの調査で確認されている9)。本報では，これを追認 し，賛否に対するそれらの影響度を評価した。さらに，参 画意欲なぞ特徵的な質問を取り混ぜ，これらの意識からも 賛否態度との関連をみていく。

\section{（1）原子力賛否の背景分析}

これまでの展開から，今後の社会のあり方に対する感 情・イメージが原子力利用の賛否態度に影響を及ぼし, 原 子力利用の (将来に打有用一無用, 安心一不安, 信頼一 不信に対する意識の背景 (一因) となっていることがわかっ た。そこには, 成長的な経済発展志向度, それを志向して いる組織や機関およびそれらを構成する者との間での意識 や利害の共通度, 経済発展への科学技術の貢献に対する期 待度, および, 成長的な経済発展で生じる犠牲に対する許 容度などがあることを示した。

ここから，原子力利用に対する賛否態度の意識背景を整 理すると, 賛成態度が強まるほど, 経済面での成長的発展 を望み, 成長的発展を志向している組織などと意識や利害 が共通している。経済成長的社会発展への科学技術の貢献 を期待し，そこで生じる犠牲を止むを得ないものと見てい る。一方, 反対態度が強まるほど経済面での成長的発展だ けを強くは望まず，そのための犠牲を認めていない。成長 的発展を最重要視している組織などとの間に理念的対立感 を抱き, 不信感を強める。そこから, 原子力利用を忌避す る意識が強く作用する傾向を読み取ることができる。

第 4 表で示した因子ごとのスコアは，賛否度と両義性 度を測る尺度になっている。第 8 図に各質問の選択肢ご との賛否に対するスコアを図示する。賛否に対して，有 用一無用, 安心一不安の影響度が偏り (非対称性)をみせてい る。すなわち, 有用性認識が賛成の根拠となる度合いより も不要性認識が反対の根拠となる度合いの方が大きい。ま た, 安心感は強く賛成感情を抱かせる(逆に, 賛成感情が 安心感を抱かせる場合もある)が, 反対感情に対する不安 感の影響度は強くない。賛成は安心から, 反対は不要性認 識から生じる傾向を読久取れ, 賛成する要因と反対する要 因が異なることがわかる。

原子力利用に対する安心一不安感情は，そのものの危険 


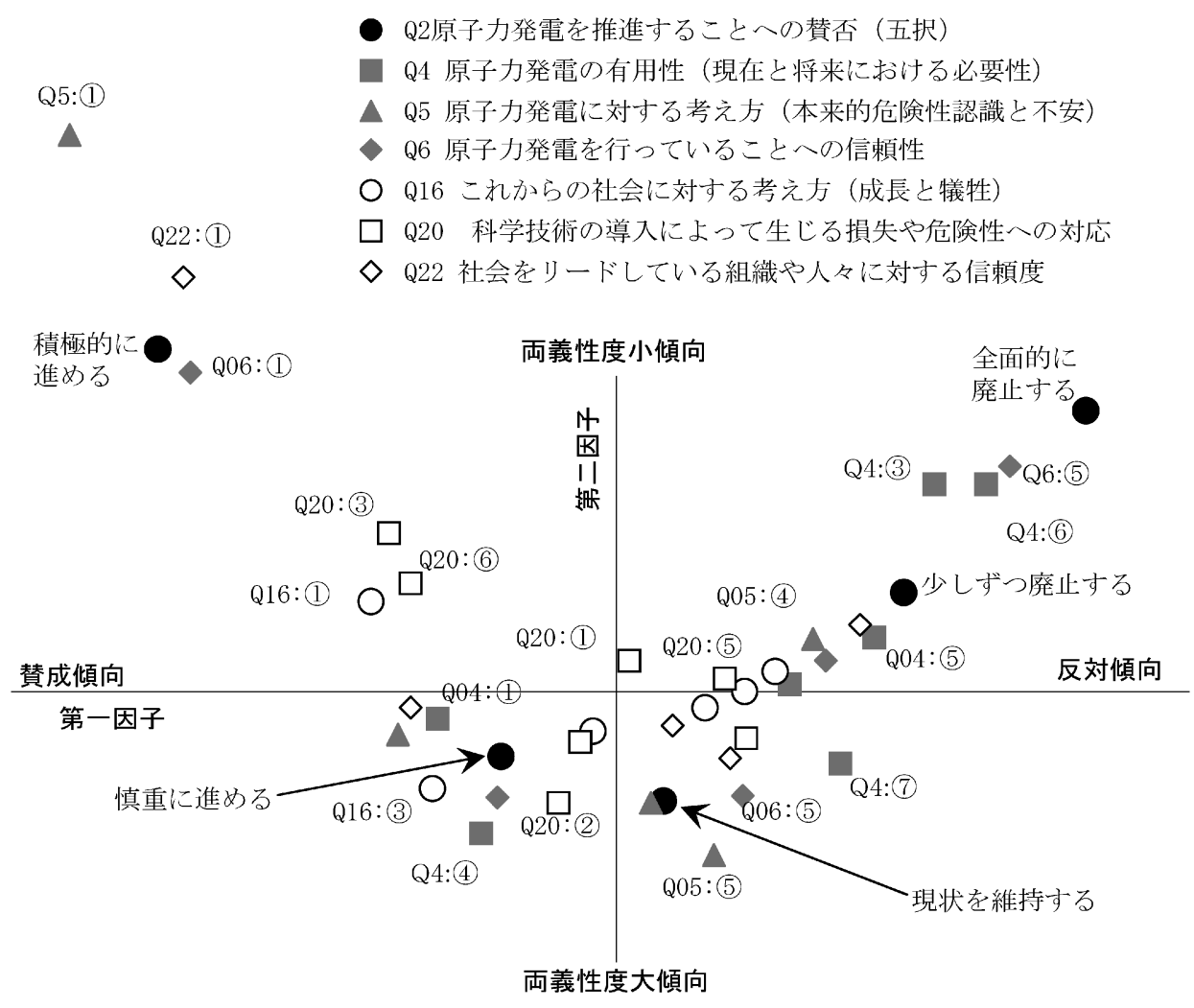

Q_:(1)〜(7)は、第3表に示した選択肢を指す

第 5 図 五択賛否との複数質問との数量化 III 類分析結果

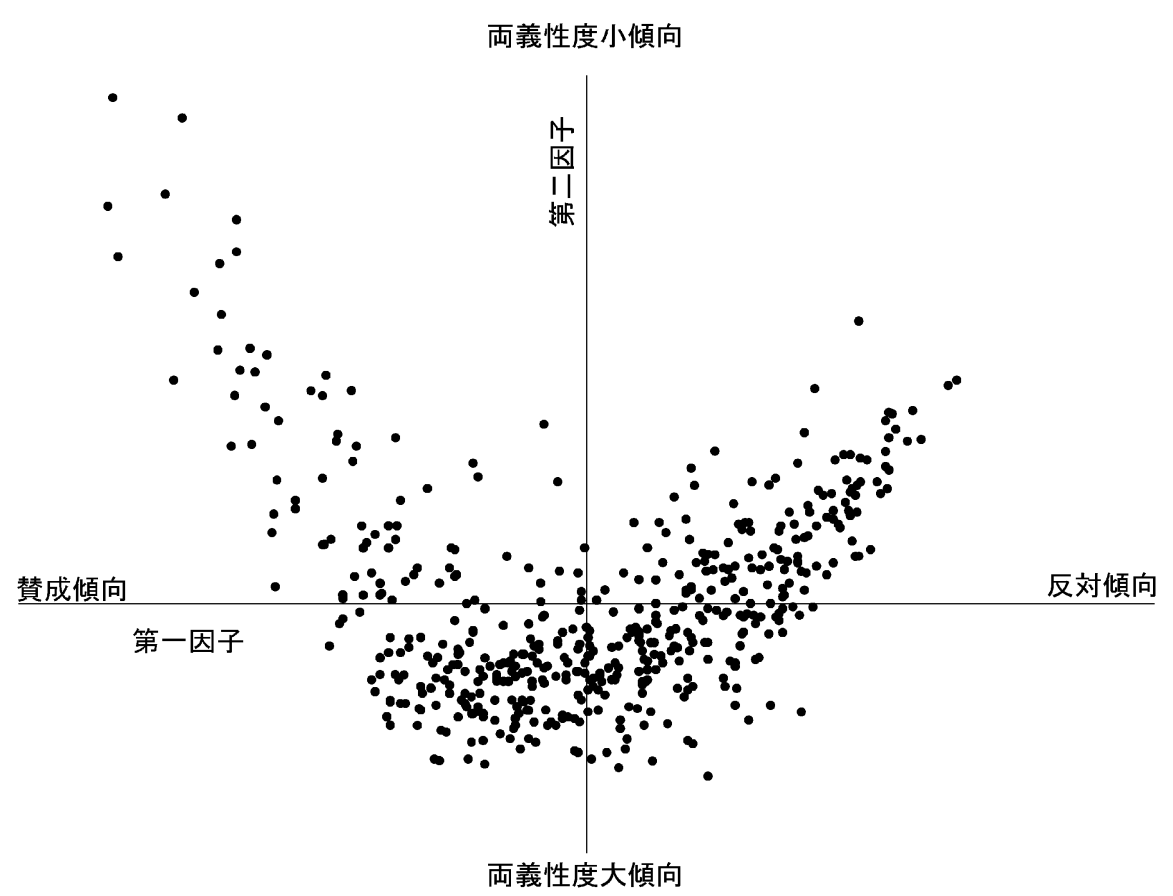

第 6 図回答者個々の総合的賛否度と両義性度の分布

性だけでなく，むしろ，その危険性を管理する組織に対す る信頼が強く影響している。原子力利用に対して不信感を 抱いている層は，信頼を判断する観点として国や原子力に 関係している組織や人の姿勢や取り組みを挙げている。姿
勢や取り組みが不信感を生む要因となっていることは，リ スクを管理する人や組織に対する疑義に結び付くものであ ると考えられる。そこから, 安心一不安と信頼一不信が結び ついていく。 


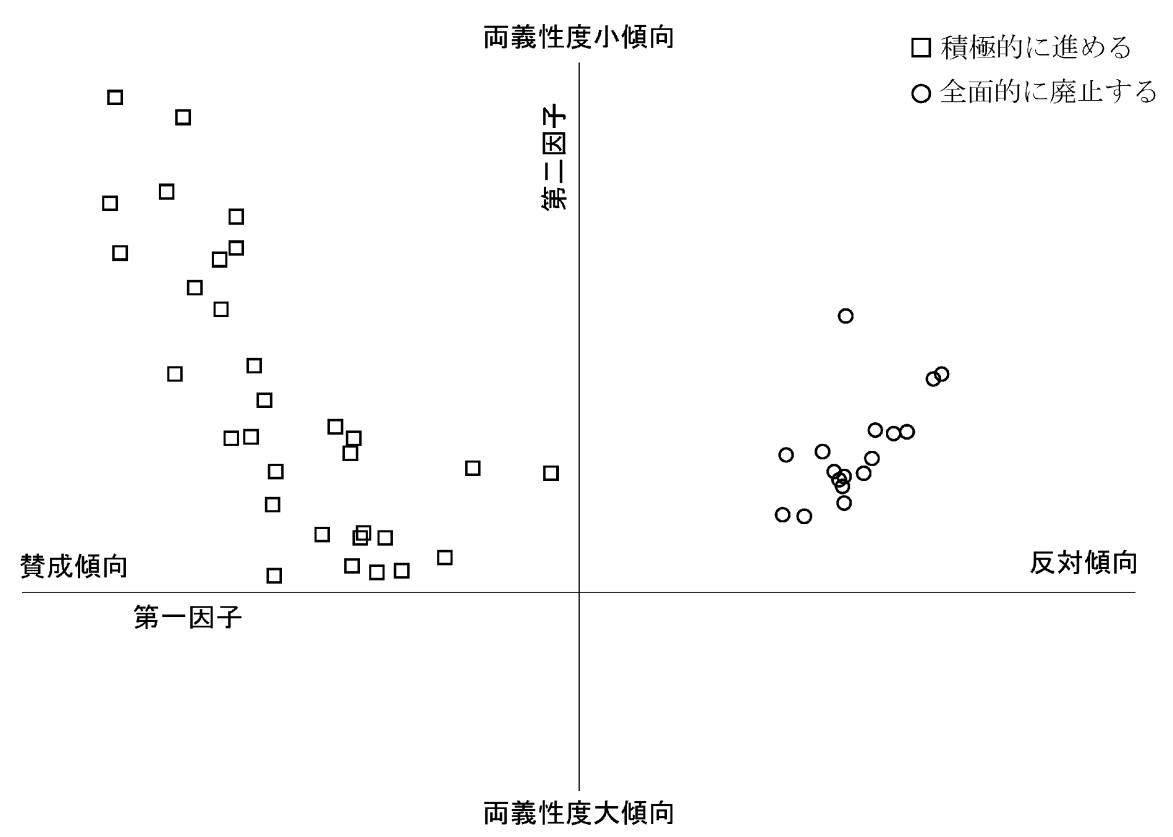

（1）強い替否態度層個々の総合的替否度と両義性度の分布

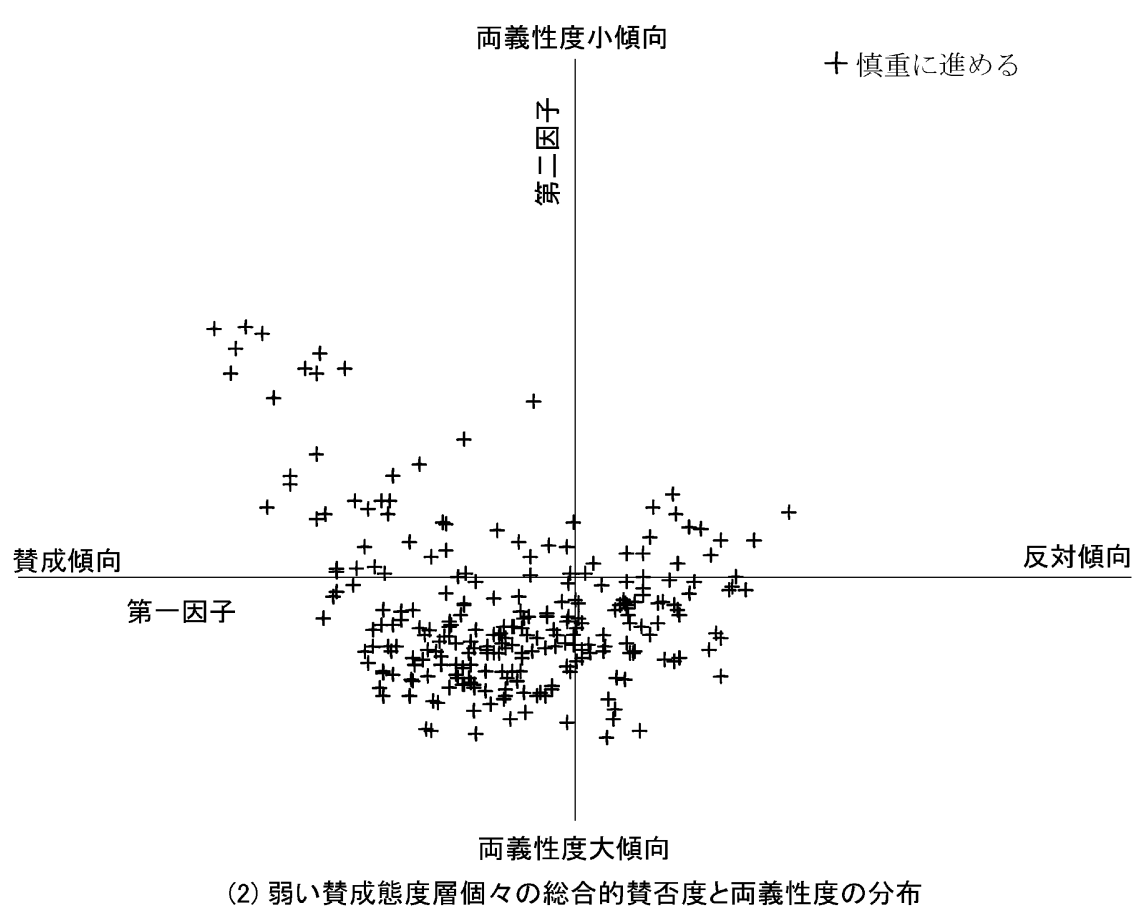

第 7 図 五択賛否層ごとの個々の総合的賛否度と両義性度の分布

一般的には，信頼はその組織の能力と誠実さに対する 認識によって規定される。一方, SVS (Salient Value Similarity) モデルでは，「相手と自分が当該問題に扔いて 重要な価值を共有していると感じると，その相手を信頼す るようになる10)」と指摘している。原子力利用を推進し ている組織と賛成層は，成長的な経済発展を重視すること で利害が共有され，その組織と組織が行っている行為に共 感し，信頼するようになる。逆に反対層は，成長的な経済 発展を重視していないことで利害が共有されず，その組織 に共感することはなく，共感し得ない行為を計画・実施し
ている組織を信頼に足るものとみない。ここから，有用一 無用と信頼一不信が結び付く。賛否に対する強い態度層 は, 賛成一反対々有用一無用, 安心一不安, 信頼-不信の連関 関係が強く，両義性意識をほとんどもたない。すなわち， 強い賛成態度は有用, 安心, 信頼で規定され, 強い反対態 度は無用, 不安, 不信によって規定される。一方, 弱い態 度層は，両義性意識をもち，賛否態度との相関が弱まる。 すなわち，相関関係からのずれが，両義性意識にほかなら ない。 


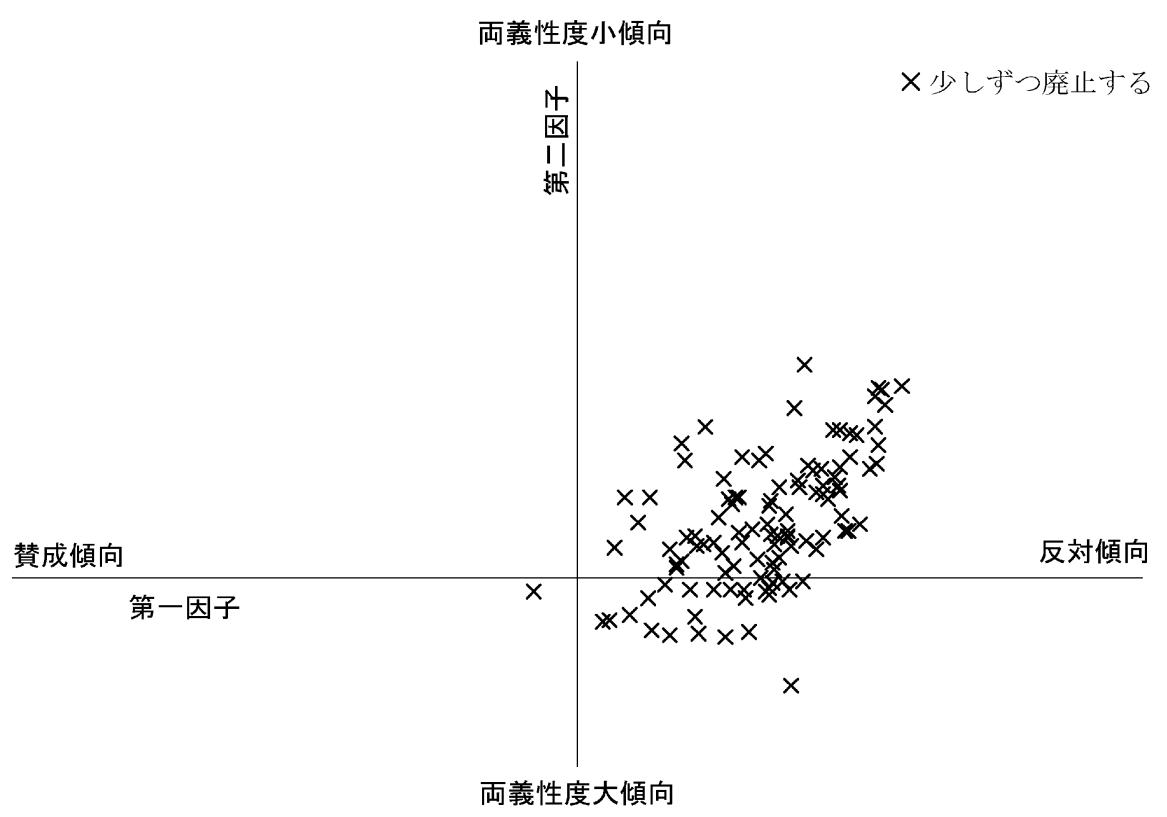

（3）弱い反対態度層個々の総合的賛否度と両義性度の分布

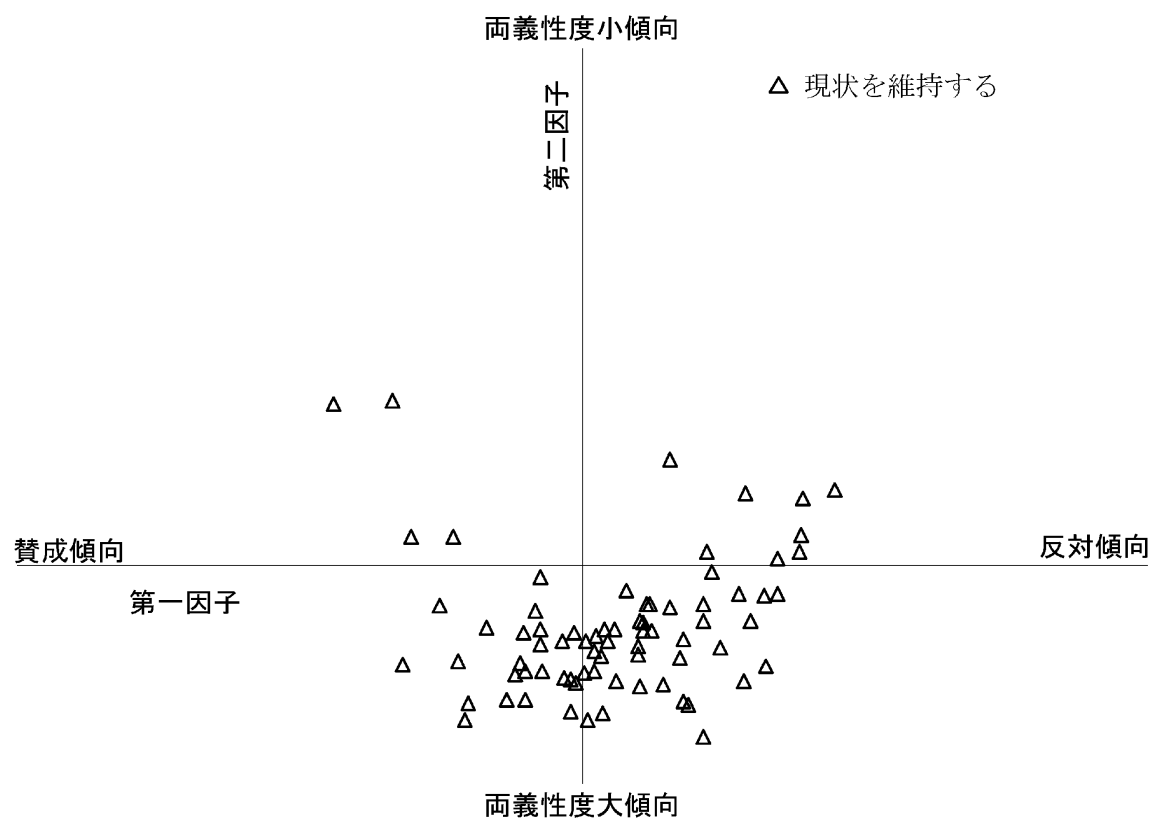

（4）現状維持層個々の総合的賛否度と両義性度の分布

第 7 図 五択賛否層ごとの個々の総合的賛否度と両義性度の分布

\section{（2）決定過程への参加/不参加による決定への納得度}

篠田 ${ }^{4)}$ は，意見が分かれていることを前提とした社会的 意思決定過程の構築を提案しており，そのためには一般市 民の意思決定過程への関与，参画が重要な役割を果たす。 そこで，自身が属する集団に扔いて，自身に不利益となる 決定がなされた場合の対応を決定場面への参加/不参加の 影響を考慮して尋ねた。質問文は付録に記すが，ここで は，属する集団の定義やどのような決定事項に関すること であるかは明示せず，回答者の状況設定に委ねた。

選択肢とその単純集計結果を第 9 図, クロス集計結果
を第10図に示す。 $40.5 \%$ が参加/不参加で異なる選択肢を 選んだ。なお，原子力利用に対する賛否態度は，「慎重に 進める」層を「慎重に進める一賛成的」抢よび「慎重に進 める一反対的」層に分け，6区分とした。第10図(1),(2)よ り，選択肢(1)は「積極的に進める」層で選択割合が高く， 賛成度合いが弱まるほど低くなることがわかる。不参加の 場合，「全面的に廃止する」層は(1)と(2)を全く選んでいな い。(4)は，反対度合いが強まるほど回答割合が高くなる。 参加の有無による変化を整理すると第10図(3)を得る。ど の層も参加によって(3)を選ぶ割合が減り，(1) と(2)が増え 
第3表の第一因子のスコアを図化

Q_:(1)〜(7)は、第3表に示した選択肢を指寸

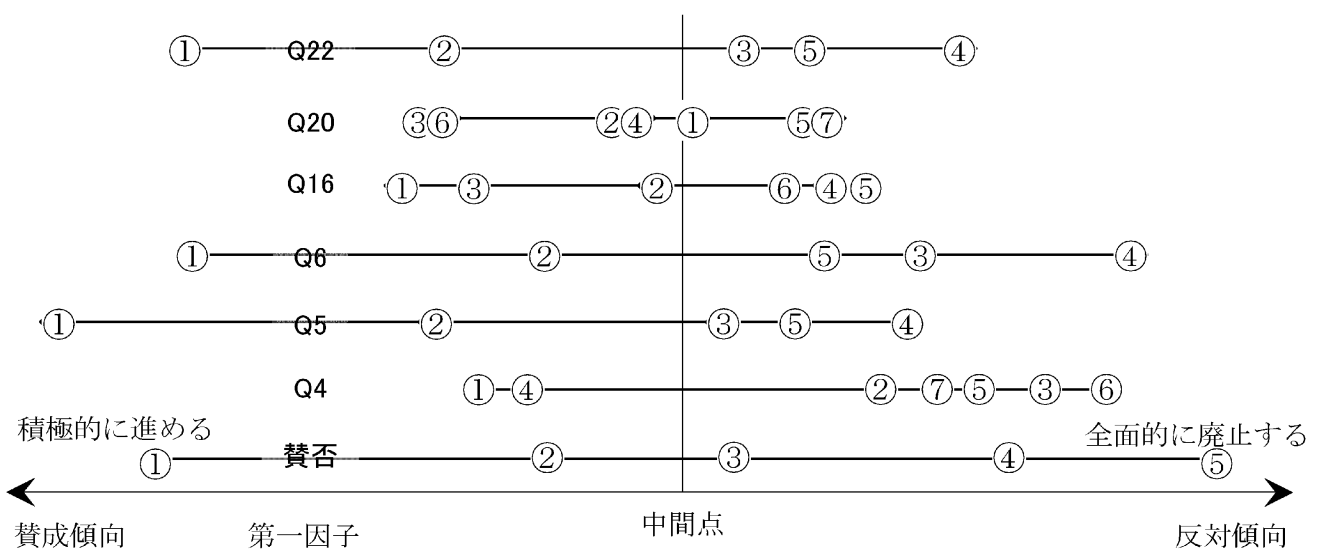

第 8 図 各質問の選択肢ごとの賛否スコア

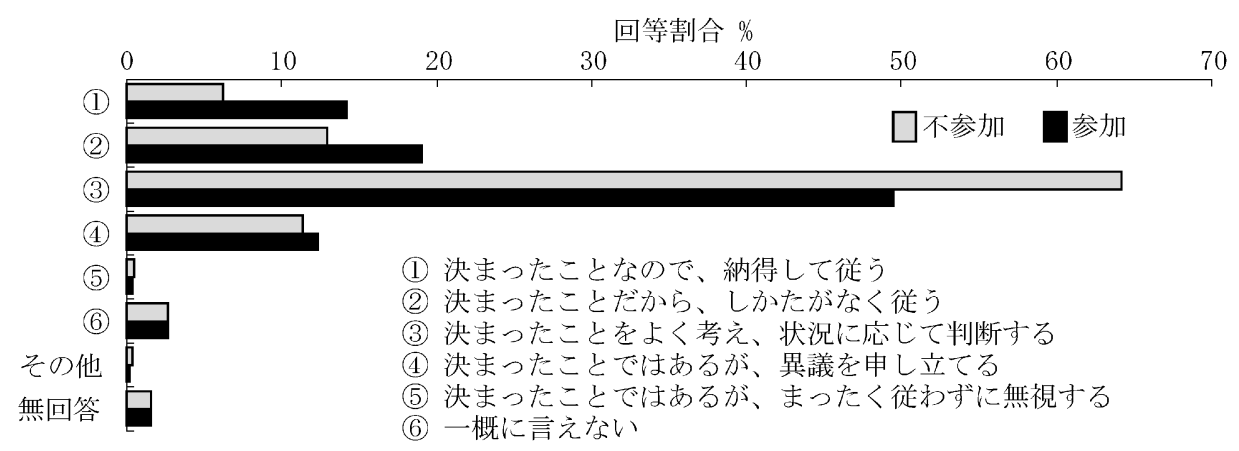

第 9 図 不利益な決定に対する対応 (参加/不参加の影響)

る。決定過程への参加によって, 不本意な決定でも受け入 れる傾向が増している。特に，「全面的に廃止する」層は 参加した場合では(1)や(2)も選択し，同時に(4)が大きく減少 している。一方，現状維持を含む賛成層で参加によって(4) が増えている。

この前に原子力利用について尋ねており，回答する上で 原子力利用に対する決定が，ここでの質問に答える際の状 況認識に結び付いたことは十分に考えられる。回答者が， 原子力利用に対する決定なのか，一般的な事項に対する決 定なのかのどちらを想定したかを分離することは本意識調 査においては難しい。また，何に関わる決定かによって， 参加/不参加の影響がぞの程度かについても判断する情報 は見当たらない。第10図に示した原子力利用に対する賛 否層ごとの差異が，一般的事項全般に打ける普遍的なもの か，原子力利用に関わることのみに限定されたものかを区 別することを難しくしてしまった。しかし，この質問は決 定過程への参加/不参加の影響をみることにある。この観 点での (例え，回答者がぞのような集団や決定事項を想定 したとしても)一側面での差異をみることには成功したと 考えている。

賛否態度とこの質問間での数量化 III 類による分析か ら, 第一因子は異議を申し立てるとする選択肢(4)と (1)(従
う)，(5)(無視する)が対極にあり，この因子は異議の申し 立て意欲の強弱を示す軸と捉えることができる。ここか ら, 異義の申し立て意欲は「積極的に進める」層が最も弱 く，以下順に「慎重に進める-賛成的」，「少しずつ廃止す る」,「慎重に進める一反対的」，「現状を維持する」，「全面 的に廃止する」層で高くなり，ほぼ賛否度と連関している ことがわかる。

第二因子は，参加/不参加を問わず(1)，(4)，(3)，(2)，(5) の順に並び，(1)と(5)が対極に，(2)，(3)，(4)がほぼ同值で(1) と(5)中間值となる。「積極的に進める」,「全面的に廃止 する」層が，(1)とほぼ同值を取る。(1)は“従う”とする姿 勢から自身が属する集団への貢献志向を表すものと，(5) “無視する”とする姿勢から非貢献志向を表すものと捉え れば，第二因子は自身が属する集団への貢献志向 (集団の ため志向)の強弱を示す軸とみることができる。

「積極的に進める」層は, (1)を有意に高い割合 (不参加で $30.3 \%$, 全回答者では $6.2 \%$, 参加で $33.3 \%$, 全回答者で は $14.2 \%$ ) で選んでいる。このことと数量化 III 類による 分析で得られた 2 因子による意識平面での配置から, こ の層が集団への貢献としての同調的な協調姿勢を有してい る傾向が強いことをうかがわせる。一方，「全面的に廃止 する」層は，(4)を有意に高い割合 (不参加で $27.8 \%$ ，全回 


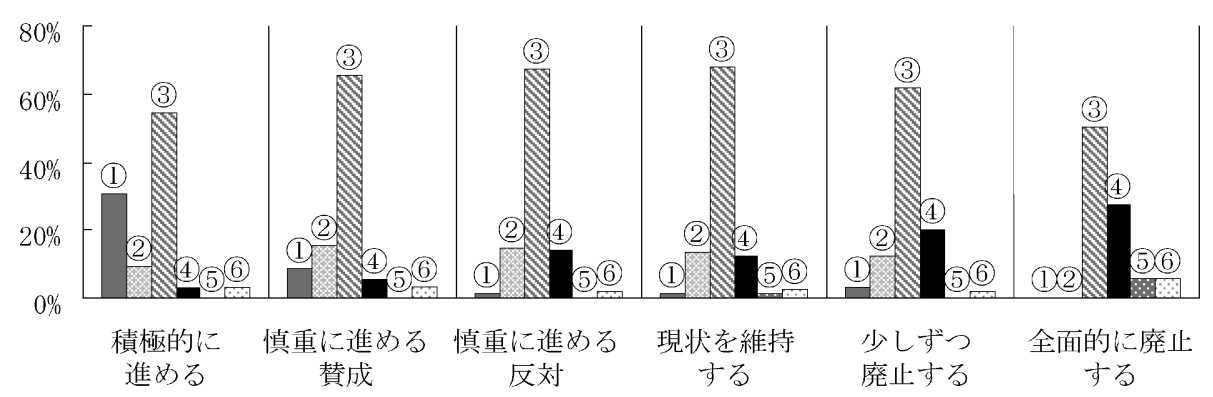

（1）不参加の場合の回答割合

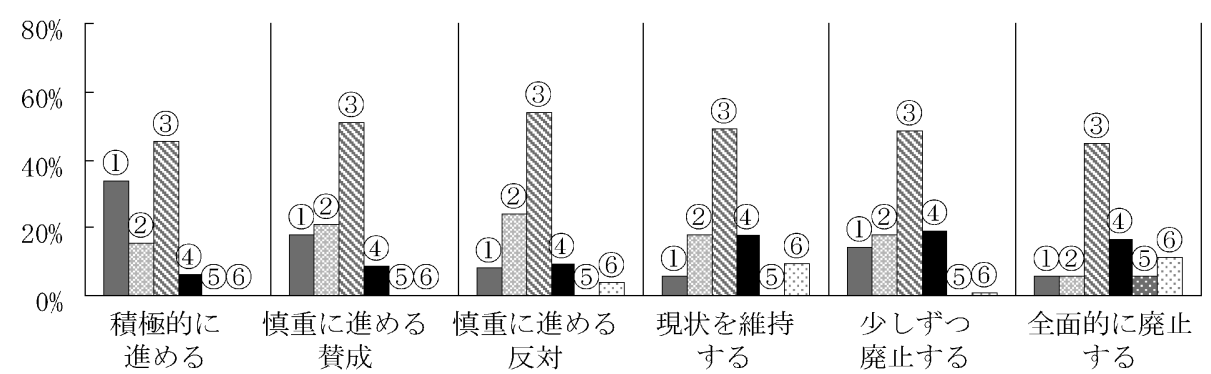

（2）参加の場合の回答割合

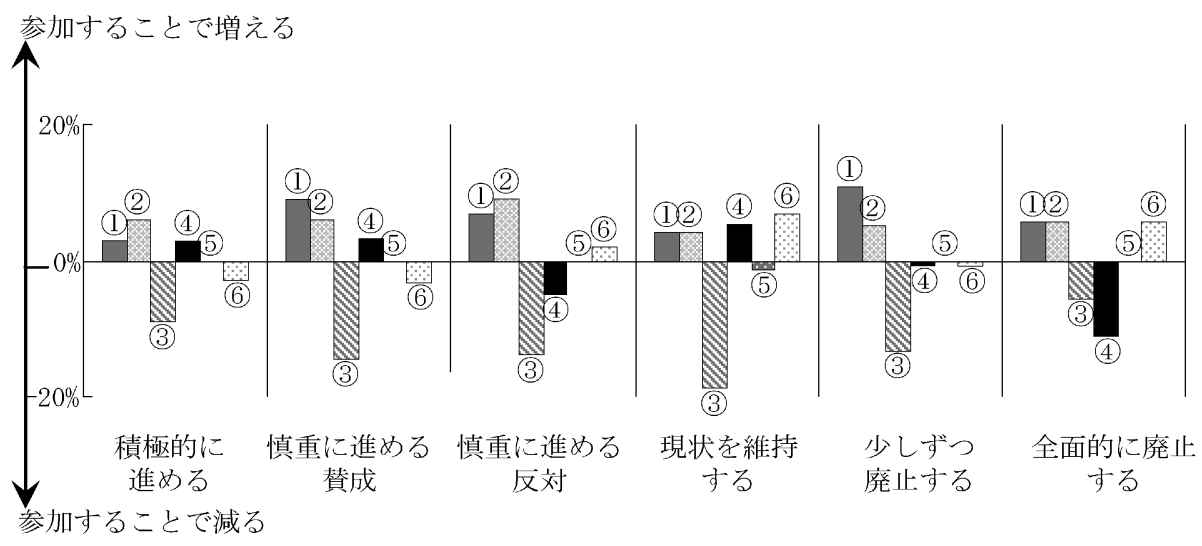

（3）参加／不参加の場合による差違

第10図 参加/不参加による対応意識のクロス集計結果

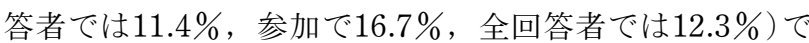
選ぶ。意識平面での配置と合わせると，「全面的に廃止す る」層は「積極的に進める」層とは異なる貢献志向をもつ ことと解釈できる。「積極的に進める」↔「全面的に廃止 する」層の貢献姿勢の意識の差違を，「例え，異議があっ ても異議を申し立てないことが協調であり，それが集団へ の貢献になる」↔「異議がある場合は申し立てることが集 団に貢献することになり，それが協調につながる」とする 姿勢と捉えると結果を解釈しやすい。

また，(2)にある「しかたがない」とする志向は非協調 (非貢献)的傾向を示し，意に反する決定においても対応行 動を取らない姿勢を示している。弱い賛否態度層には, 「何もしない，しかたがない＝非貢献的，貢献し得ない」 とする意識傾向があると解釈できる。

特徵で整理すると, 自身に不利益な決定に対して,「全
面的に廃止する」層は異議を申し立てる，「少しずつ廃止 する」層は状況に応じて判断する,「弱い賛成一反対的」層 は“しかたがない”意識が強い，それに対して，「弱い賛 成一賛成的」層と「積極的に進める」層は “従う”特性を 有する傾向があるものと解釈できる。

\section{（3）国/地域レベルの科学技術政策への参画意欲}

国レベル(例えば原子力発電や遺伝子組み換え食品の導 入など科学技術の導入 ·推進に関わる事項) と地域レベル (例えば原子力発電所の建設などに関わる事項)における科 学技術政策の意思決定過程への参画意識を尋ねた。選択肢 (複数選択可)は同一とした。集計結果は以下となった。

(1) 常に自分の意志で関わっていきたい

17.4\%/18.7\% 国/地域レベルの結果(以下，同様)

(2) 場合によっては自分の意志で関わっていきたい $25.2 \% / 27.8 \%$ 
(3) 自分の意志で関われるところから関わっていきたい $45.0 \% / 42.3 \%$

(4) 自分の意志で関われるよう意欲や知識を高めていき たい $39.7 \% / 35.6 \%$

(5) 自分の意志で関われるように参加の手段を模索した い $13.8 \% / 17.2 \%$

(6) 自分の意志で関われるように参加の手段を作ってほ しい $27.4 \% / 23.8 \%$

(7) 自分の意志で関わるべきではない $1.5 \% / 1.3 \%$

８）自分の意志で関わることはできない

$5.4 \% / 5.1 \%$

(9) 自分の意志で関わることはしない

$4.2 \% / 4.7 \%$

(11) 一概にいえない

$5.1 \% / 4.7 \%$

積極的な意欲を示す選択肢 (11，(2)，(5)）で地域レベルが やや高い。それらよりも若干積極性が低い意欲を示してい る選択肢 (3)，(4)，(6) は国レベルの方が高く，しかも選択 割合も高い。自身の生活に直結する身近な問題として，例 えば街づくりなどに住民が決定過程に関わる機会が増えつ つある。市民が，科学技術に関わる決定と街づくりなどに 関わる決定を区別して考えているか否かは本調査では確認 できないものの科学技術に関わる決定において，参画意欲 が高い地域レベルに対して，国レベルでは関与の道は不十 分と認識しつつ，その上で参画を求めているものと解釈す ることができる。

この質問と決定過程への参加/不参加による影響を尋ね た質問，および五択賛否態度との間で数量化 III 類による 分析を行った。第一因子は, 参画意欲の低い選択肢 (7), (8)，(9)）が大きなスコアをもつことから，参画意欲の強弱 を示す軸と捉えることができる。五択賛否態度のスコアか ら，賛否態度層ごとの参画意欲の傾向を掴むことができ る。そこから，参画意欲は「全面的に廃止する」層が最も 強く，以下順に，「少しずつ廃止する」，「弱い賛成一反対 的」「弱い賛成-賛成的」，「現状を維持する」，「積極的に 進める」層となる。

賛否態度との残差分析から，「全面的に廃止する」層は (1)を有意に高い割合で選択し，国レベルへと地域レベルへ の参画を両方とも強く求めていることがわかる。一方, 「積極的に進める」層の国レベルへの参画意欲は低く, 関 わらないとする意識も高い。

また，原子力利用に対する興味・関心および自分への関 わりを尋㱛た質問間での分析から，興味・関心と自分への 関わりがないと回答した層は，参加への自身の強い意思が 伴うものを選ぶ割合が低いことがわかる。同時に(7)，(8) 選んで抢らず，参加の有効性をすべて否定してはいないも のの負担の少ない参加-(3)や参加への依存-(6)抢よび，参加 しない意思-9を選んでいる。興味・関心抢よび自分への
関わり意識が低ければ参加意欲は低くなること，また， 「弱い賛成一反対的」層は「弱い賛成-賛成的」層より興味 . 関心が低いことがわかる。

\section{IV. 提 言}

人は，こうありたいとする願望から自身が望んでいる将 来社会のイメージを抱く。そして，そのイメージは広く分 散し, 利害が共通した特定将来イメージの共有が薄れつつ あると捉えられる。伝統やしきたりに対する意識などを尋 ねた継続的な社会意識調查 ${ }^{11)}$ から，現代社会では追従的 な姿勢からの脱却が顕著な流れとなっていることが読反取 れ，与えられたイメージに追従する意識が薄れつつあるこ とは明らかな流れだと思われる。さらなる成長的社会を望 む者の割合は減少傾向にある。これは，内閣府が実施して いる国民生活に関する調査 ${ }^{12)}$ に打悩る心の豊かさを求め る層の増加からも裏付けられる。本調査では調査結果の経 時変化は追えないが，本調査結果が示す将来社会のイメー ジに対する見解の別れが，時代の経過とともに大きくなっ ていることは確かではないかと思われる。

原子力利用の賛否が，成長的社会志向度合いと関連して いることを本調査が明らかにした。そこには，市民が「ど のような社会を望むか」が大きく関わり，この意識は「ど のような暮らし方，生き方を望むか」と等価である。そし て，暮らし方・生き方とは，市民の日常生活に関わる事項 であり，原子力利用に関わる事項は高度に科学的・専門的 事項であると同時に市民の日常生活を左右する事項にもな っていく。日常生活を左右する事項であれば，市民で話し 合いながら，その動向を見い出すことは社会の基本であ る。この観点から，原子力利用の動向を見い出すための意 思決定過程に市民が加わることは当然なことと受け止めら れる。

原子力利用の是非を巡る論争は，将来社会の望むべき方 向性の議論から始める必要があり，その議論は一般市民が 参画した上で方向性を見い出すことを念頭としたものであ ることが望まれる。これまでは成長的社会志向を前提とし た上で原子力推進者が市民に理解を求めるとする形の議論 展開が推し進められていた。これでは，協働の観点からみ れば，一般市民の参画による意思決定とはいい難い。

本調査で存在を確認した「慎重に進める一反対的」層は, 原子力利用に対して反対的意識を多く有しても“賛成”し， 「少しずつ廃止する」とは回答しない。本報で明らかとし た原子力利用に対する総合的態度では，「慎重に進める一反 対的」層と「少しずつ廃止する」層では意識の重なる部分 が存在し，表明する意見を分ける明確なしきい值は見当た らず，安心，信頼，有用性意識などの差違では両層を明確 に分けることができない。

これまで，「慎重に進める」と回答する弱い賛成層は, 表明する意見から賛成層として扱われていた。篠田 $\left.{ }^{4}\right)$ は弱 い賛成態度層に着目し，原子力利用が扔かれている社会状 
況に及ぼす影響について考察し，以下の影響メカニズムに よって原子力利用の賛否に対して強い影響を及ぼしている ことを示した。

- 強い賛否態度層が, 原子力利用に問題点を発掘 し，問題として提起する。(問題発掘段階)

- 弱い賛否態度層は, その動きによって問題の存在 に気付き，当該事象を社会問題と捉えるようにな り，社会的関心事となっていく。(気付きの段階)

-この過程で, 潜在的な志向としての弱い賛否態度 層は, 当該事象 (ここでは原子力利用)が社会的関心 事となっていくことで“傍観者”から“懸念を抱き, 不安を表明する傍観者”と変貌していく。（態度の 形成段階）

- 多くの弱い賛否態度層はこの過程で意識を変え, 態度を変えるまでには至らないが，意識の背景とし ての両義性意識のバランスは変化する。

・この様相が，弱い賛否態度層の賛否背景を通して 社会の雾囲気に変化を及ぼす。（雾囲気への影響段 階）

- 社会の䨌囲気の変化が, 強い態度層の問題発掘 . 提起活動を活発化させる。（問題の再励起段階）

- 問題発掘 - 提起活動の活発化が, 当該事象を社会 問題として,より意識されていく。

・この過程において, 弱い賛否態度層の態度は, 賛 否の背景を摇らぎやすいものとしていく。

・ その摇らぎが, 原子力利用がおかれている社会状 況に大きな影響力を及ぼす。

原子力利用と社会の関係に打ける “理想像” としての共 進化には，一般市民が自由に意見を表明し，反映できる状 況が重要である。「慎重に進める一反対的」層が表明する態 度と意識の背景を異にすることが, 意識的なのか, 無意識 的なものなのかを判別することは本調査ではできない。し かし，この層は自身の意見を表明することを躊躇し，“不 明確な”態度を取っている。なお，ここでの表明とは公の 場などで意見を述べることを指すのではなく, 今回の郵送 による意識調査の段階でも自身の心理と逆の回答を意識 的/無意識的に関わらずにしてしまうことを表明しないと 捉えたものである。意見をいわない・いえないとするこの 態度は，原子力利用に対する懐疑的な心情が “潜伏”して いるものと捉えることもでき, “わだかまり”的な違和感 を生んでしまう要因とも考えられる。そこから, 事故や不 祥事などの発生による刺激によって, 潜んでいた感情が表 出し, 社会的雲囲気の変化(いわゆる逆風) として現れてい く。このような意識傾向が，原子力利用を巡る是非判断を 複雑なものとし，原子力利用に関わる社会の䨌囲気を变わ りやすいものとしているといえる。

不明確な態度を取る背景には個人特性とともに様々な社 会的要因があり, 両面からの改革が望まれる。表明する意 見と心理が異なる一因には, 原子力利用に関わる意思決定
過程に対する見方が関わっているものと捉えることは, 本 調査で完全に検証しきれなかったものの妥当ではないかと 思われる。手続き的公正e) 概念を導入し, 決定過程への参 画が当該事項に対する人々の印象形成に重要な役割を果た すことが確認されている13)。

本調査においても, 決定過程への参加/不参加の影響や 科学技術に関わる事項に対する参加意欲などから，多くの 市民がなんらかの形で参画を求め, 参画した上での決定な ら納得する意向を有していることを示した。そこでは， “対話”が両面から改革の手掛かりとなる。原子力利用に 関する意思決定において, 対話の重要性が叫ばれてい る ${ }^{14,15)}$ 。原子力界では, 意思把握としての(広報・公聴の 一環としての)対話を実践する活動が推進されているもの の今後の動向を見い出す (問題解決の)ために必要な意思疎 通としての対話が実践されているとはいい難い。対話の先 には，意思決定過程への参画が開かれていなければならな い。手続き的公正を遵守し, 決定項目に対して修正可能性 （決定は不変ではなく, 対話の過程で柔軟に変更し得る可 能性）を否定しない意思決定過程が市民の参画意欲を高 め, 信頼感も醸成されていくことが指摘されている16)。 不明確な態度は, 受動的な姿勢によって形成されやすく, 決定に対する能動的な立場を構築することで是正を図るべ きである。

本報は意識調査結果から，意思決定過程に対して，およ び，そこでの決定によって被る可能性のあるリスクに対し て受動的姿勢をみせている市民の存在を指摘し, 市民が原 子力利用を自分の問題として捉え直し，そして主体的な関 与を促すための方策を提言するものである。

リスク(リスクを伴う行為)について直接, 間接的に関わ らず関係者間で意見を交換する試みとして，リスクコミュ ニケーションが率先されている。原子力利用に対するリス クコミュニケーション活動は, 谷口ら ${ }^{17)}$ の先導的試みに 始まり，市民・住民と原子力事業者の間の意思疎通を目指 して活動が行われていた。また，市民・住民との対話を実 効的なものとする先進的な試みが，八木，北村ら18)によ って, 社会的意思決定への展開を視野に遂行されている。 これらの活動は, 原子力利用の是非に対して説明・説得の 観点を主眼としていたこれまでの展開に一石を投じるもの である。また，化学物質や環境などに対する一般的なリス クコミュニケーションの捉え方に拈いて, 関沢19)や織20) が発展段階として定義の变遷をまとめている。そこでは, 第一段階: データの提示段階（技術的な情報提供, 開示, 広報) から, 第二段階: 情報の提供段階 (教育, 宣伝, 解 説, 説得手法の獲得)を経て, 第三段階: 共通ベースと意

\footnotetext{
e) 社会心理学の研究成果13) として,「決定の適切さ」以上に「手 続きの公正さ」が重視されることが指摘されており，これは決 定過程への信頼がすべての信頼の基礎となることを意味してい る。ほとんどの場合で, 人々は決定内容のいかんに関わらず手 続き的公正を感じると満足度が高まることも指摘している。
} 
見交換段階(責任ある参画と手続き的公正さを重視)に至る ことがリスクコミュニケーションの確立であり, 第三段階 に至るために必要なこととして，判断基準と結果の関連を 提示する必要性を強調し, 意思決定過程の透明性を求めて いる。

原子力利用における意思決定において, 決定したことの 「受け入れ」を社会に求めることに集中し, 修正可能性は ほとんどなかった。また, 原子力利用の前提となる将来社 会のイメージは固定的で, 社会に示すものであった。これ に固執することが “閉鎖性”を際立たせてしまい, 同時に 社会の意識の変化に適応する能力を失わせてしまう。意思 決定に関わる者が，市民の参画を促し，誰もが意見をい え, どのような意見であろうとも反映される可能性を否定 されていないとする認識を市民と共有し, 協力して今後の 動向を探っていくことを意思決定の基本とすべきである。 そこから, 相互に信頼感が醸成されていく。相互の信頼感 が原子力利用を円滑に進める鍵となる。そのためには, 多 くの者が “それでよい”と認めた意思決定プロセスで創出 された決定を“正しい”ものとして選択する考え方に意識 を変えていかねばならない。そのような意思決定プロセス を構築していくことが, 共進化の具現化であり, 原子力利 用を「止むを得ない行為」から「自身の意思による選択に よって実施されている行為」として, すなわち主体的行為 としてみることを可能とする。「止むを得ない行為」では, “わだかまり”的な意識が反映されて過度に安全性を要求 し，その行為による損失(の可能性) は許容され難くなる。 「止むを得ない行為」から脱却することで，原子力利用に 伴うリスクにも立ち向かうことができるようになってい く。リスク概念には, “危険・損失” と “恩恵·利益” の 量とその可能性がそもそも含まれており, 選択 ( = 意思決 定)が内包されたものであると捉えることが重要となる。

多くの市民が原子力利用に対する姿勢と原子力界が進め ようとする方策の差異を浮き彫りにし，その原因を見極め ることで「自らを省みる」ことが可能となり，今までみえ なかったことがみえてくる。原子力は，社会技術の先鞭と して積極的に社会に開かれたものとなるべき展開を期待さ れる存在である。その上で, 原子力利用を社会の中で円滑 に進めるためには,「これからどうするか」をともに判断 していく過程を重視することであり, 結果の正当性を強調 するのではなく, 決定過程の正当性を確保し, その認知を 得るべきである。

\section{V.おわりに}

これまでに実施された意識調査結果を俯瞰的に分析し， 検討した結果の実証を行い, 弱い賛成態度層の意識背景の もち方などに対する仮説を検証することに成功した。さら に，原子力利用に対する賛否態度と社会意識(生活を営む 意識) との関連を調べ, 今後の社会動向として経済成長志 向をもつか, そこへの科学技術の貢献や功罪にどのように
目を向けているか，そして，社会的事項全般にどのように 向かい合うか(自分の価值観一集団の価值観のどちらを優 先するかなど)によって, 原子力利用への態度が影響され ることを確認した。そこから, 原子力利用を巡る意思決定 過程を見直すことが，原子力利用をさらに推進するための 方策となり得ることを示した。

意識調査は，「自らを省みる」ための貴重な情報を得る ものと捉えることが重要である。「自らを省みる」ことか ら調査結果に基づいた“新たな気付き”を生み出し, それ を展開させることが重要である。その過程で原子力と社会 (一般市民) の共進化が具現化されていく。

\section{一参考文献一}

1）鳥井弘之, 科学技術文明再生論一社会との共進化関係を取り 戻せ, 日本経済新聞社出版局 (2007), ISBN978-4-53216579-6.

2) 東京工業大学 21 世紀 $\mathrm{COE}$ プログラム, 世界の持続的発展を 支える革新的原子力, 研究 - 教育活動 成果報告書, 最終報 告書, 164-248 (2007), ISBN978-4-903054-23-0.

3）柴田鐵治, 友清裕昭, 原発国民世論, ERC 出版（1999）.

4）篠田佳彦, “原子力と社会の相互作用に関する研究, ” 日本原 子力学会和文論文誌, 6[2], 97-112 (2007).

5) 内閣府, エネルギーに関する世論調査,〈http://www8.cao. go.jp/survey/h17/h17-energy/index.html (2006)「最終訪問 日2008年 6 月 25 日」.

6）藤井 聡, “リスク態度と注意一状況依存焦点モデルによるフ レーミング効果の計量分析一, ”行動計量学, 28[1], 9-17 (2001).

7）土田昭司, 伊藤誠宏, 若者の感性とリスク一ベネフィットか らリスクを考える, 北大路書房 (2003).

8） NHK 放送文化研究所編, 現代日本人の意識構造 [第 6 版], 日本放送出版協会（2005）.

9）木村 浩, 古田一雄, 鈴木篤之, “原子力の社会的受容性を判 断する要因一居住地域および知識量による比較分析, ”日本 原子力学会和文論文誌, 2[1], 379-388 (2003).

10）中谷内一也, “信頼のSVS モデル (1) : 水源湖の環境リスク 論争事例, ”日本社会心理学会第46回大会 予稿集 (2005).

11）統計数理研究所編, 国民性の研究 第11次全国調査, 統計数 理研究所 研究リポート92 (2004).

12）内閣府大臣官房政府広報室, 国民生活に関する調査, 〈http:// www8.cao.go.jp / survey / h19 / h19-life / index.html > (2007) 「最終訪問日 2008 年 6 月 25 日」.

13) E. Allan Lind et al, フェアネスと手続きの社会心理学, 菅原 郁夫, 大淵憲一訳, ブレーン出版 (1995).

14）原子力委員会「市民参加懇談会について」, 〈http://www. aec.go.jp/jicst/NC/simin/index.htm>(2008)「最終訪問日 2008 年 6 月 25 日」.

15「「原子力のすべて」編集委員会編，原子力のすべて一地球と 共存する知恵一：原子力について対話のできるホームペー ジ,〈http://www.aec.go.jp/jicst/NC/sonota/study/aecall/ index.html $>$ (2003)「最終訪問日2008年 6 月 25 日」.

16）藤井 聡, “合意形成問題に抢ける “計画修正可能性” “ “謝 罪” の決定的役割, 運輸政策研究, ” 7[3], 2-9 (2004).

17）谷口武俊, 他, 原子力技術リスク $\mathrm{C} 3$ 研究 : 社会との対話と 協働のための社会実験, 〈http://tokaic3.fc2web.com/body/ report/report_h16/H16full.pdf $\rangle(2006) 「$ 最終訪問日2008年 
6 月25日」.

18）八木絵香, 高橋 信, 北村正晴, “「対話フォーラム」実践に よる原子力リスク認知構造の解明, ” 日本原子力学会和文論 文誌， 6[2]，126-140（2007）.

19）関沢 純, 化学物質・環境問題のリスクコミュニケーショ ン, 〈http://www.env.go.jp/chemi/ communication/taiwa/ text/risukomi.pdf $>(2002) 「$ 最終訪問日2008年 6 月25日」.

20) 織 朱實, 化学物質による環境リスクとリスクコミュニケー ション, 科学と工業, 78[8] 17-23 (2004).

\section{付録 質問票と集計結果}

はじめに，原子力発電についてお伺いします。

Q1.これからのエネルギー源として, 原子力発電を推進 することに対してどのように思われますか。

(1) 賛成 $(58.1 \%)$, (2) 反対 $(25.2 \%)$, (3) その他 (14.9\%)

Q2. 同じ質問を以下の選択肢から答えいただく場合 は，どのように思われますか。

（選択肢は本文中に記載）

Q3. あなたは, 原子力発電に興味や関心がありますか。 そして，原子力発電は自分に関わりのあることだ思われ ますか。

(1) 興味や関心があり，自分に関わりのあることだと思 う $(53.9 \%)$

(2) 興味や関心はあるが自分に関わりのないことだと思 う (10.5\%)

(3) 興味や関心はないが自分に関わりのあることだと思 う $(28.3 \%)$

(4) 興味や関心がなく, 自分に関わりのないことだと思 う $(2.0 \%)$

(5) 一概に言えない $(3.8 \%)$

Q4. 原子力発電は役に立っていると思われますか。 （選択肢は本文中に記載）

Q5. 原子力発電について，どのように思われますか。 （選択肢は本文中に記載）

Q6. 漠然とした質問ですが，あなたは，原子力発電を行 っていることを信頼していますか。

（選択肢は本文中に記載）

Q7.どのような観点から，【Q6】の答えをお選びになりま したか。（複数回答可）

(1) 技術的な観点 (44.3\%)

(2)これまでの実績 (49.7\%)

(3) 原子力に関係している組織が取り組む姿勢 (39.2 \%)

(4) 原子力に関係している人, 個々人が取り組む姿勢 (24.0\%)

(5) 国が原子力行政に取り組む姿勢 （32.8\%）

(6) 国の規制や安全確保に対する取り組み (43.9\%)

(7) その道の専門家の意見 $(5.4 \%)$
(8) 身近で信頼している人の意見 $(2.0 \%)$

(9) マスコミの報道 (9.3\%)

(10) 社会の䨌囲気 $(4.7 \%)$

(11) 信頼するしかない $(22.7 \%)$

(12) その他 $(4.7 \%)$

(13) そもそも信頼していない（0.7\%)

Q8. 原子力発電はどのような恩恵をもたらすと思われま すか。（複数回答可）

(1) 便利で安定な生活 (41.0\%)

(2) 日本社会の経済発展 (35.4\%)

(3) 発展途上国などの今後の発展 $(8.7 \%)$

(4) 秩序だった社会の維持・形成 (5.6\%)

(5) CO2 の発生を抑え, 地球温暖化防止 (49.4\%)

(6) 経済と環境の両立 (19.2\%)

(7) 化石燃料の代替 $(54.6 \%)$

(8) 石油資源などをめぐる争いの回避 （34.3\%）

(9) 石油の有効利用 $(14.2 \%)$

(10) 核兵器の削減 (4.0\%)

(11) その他 $(1.6 \%)$

(12)何も連想しない $(2.7 \%)$

Q9. 原子力発電はどのような犠牲をもたらすと思われま すか。（複数回答可）

(1) 死傷や健康被害などの人的な被害 $\quad(68.2 \%)$

(2) 経済的な被害 (6.4\%)

(3) 生活環境や自然環境への被害 (56.6\%)

(4) 日本国内での対立や緊張関係の発生 (16.0\%)

(5) 国際関係の中での対立や緊張関係の発生 (9.8\%)

(6) 不安やおびえなどの感情を持つ方々の増加（30.5 $\%)$

(7) 不満を抱く方々の増加 (12.5\%)

(8) 核兵器開発 $(27.6 \%)$

(9) 管理体制の強化 (15.4\%)

(10) テロの脅威 $(51.2 \%)$

(11) その他 $(1.1 \%)$

(12)何も連想しない（1.1\%)

次に，社会意識(生活を営む意識)について伺いします。

Q13.あなたの社会貢献に対する意識はいかがですか。

(1) 自身の負担が伴っても積極的に社会に貢献する (4.2\%)

(2) 自身の負担が伴っても出来る範囲で社会に貢献する (30.7\%)

(3)自身の負担が多少であれば，社会に貢献する (20.3\%)

(4) 他の人も同様な負担を負えば自分自身も社会に貢献 する $(10.2 \%)$

(5) 自身の負担が伴わない範囲で社会に貢献する（8 $\%)$

(6) 個人を活かす(自分のできる)ことで社会に貢献する 
$(21.8 \%)$

(7) 個人がよければ社会の事はかまわない（0.4\%)

(8) 一概に言えない $(2.4 \%)$

Q14.あなたが決定する場面に参加していない状況で，あ なたが属する集団が決めたことであなたの利害が損なわれ る可能性があるとします。ここで決めたことには，従わな くとも法律違反になることはありませんが，場合によって は，従わないことでさらに不利益を受ける場合があるかも しれない状況を想定してください。あなたはどうします か?

(1) 決まったことなので, 納得して従う (6.2\%)

(2) 決まったことだから，しかたがなく従う（12.9\%)

(3) 決まったことをよく考え，状況に応じて判断する (64.2\%)

(4)決まったことではあるが，異議を申し立てる $(11.4 \%)$

(5) 決まったことではあるが，まったく従わずに無視す る $(0.5 \%)$

(6) 一概に言えない $(2.7 \%)$

Q15.では，あなたが決定する場面に参加した状況で，あ なたが属する集団が決めたことであなたの利害が損なわれ る可能性があるとします。ここで決めたことには，従わな くとも法律違反になることはありませんが，場合によって は，従わないことでさらに不利益を受ける場合があるかも しれない状況を想定してください。あなたはどうします 加?

(1) 決まったことなので, 納得して従う (14.2\%)

(2) 決まったことたから，しかたがなく従う（19.1\%）

(3) 決まったことをよく考え，状況に応じて判断する (49.5\%)

(4)決まったことではあるが，異議を申し立てる (12.3\%)

(5) 決まったことではあるが，まったく従わずに無視す る $(0.4 \%)$

(6) 一概に言えない $(2.7 \%)$

Q16.これからの社会はどのようにしていくべきだとお考 えですか。

(1) 多少の犠牲があっても成長を基盤とした社会を目指 す $(17.1 \%)$

(2) 今後も成長を望むが何かを犠牲にするなら現状でも よい $(24.7 \%)$

(3) 一層の成長は望なないが現状維持の為の犠牲は許容 する $(8.7 \%)$

(4) 現状維持を望むが何かを犠牲にするなら後退も仕方 ない $(12.3 \%)$

(5)成長よりも犠牲の少ない穏やかな社会を目指す (27.9\%)

(6) 一概に言えない $(6.5 \%)$

Q17.上の質問 $(\mathrm{Q} 16)$ の 中で「犠牲」という言葉からどの
ようなことをイメージされますか。（複数回答可）

(1) 自然環境 $(71.7 \%)$

(2) 文化 (18.5\%)

(3) 伝統(慣わし) (18.7\%)

(4) 人間性(自分らしさ) $(31.6 \%)$

(5) 人同士の結びつき (助け合い) （31.0\%)

(6) 国際関係(平和) $(27.2 \%)$

(7) 暮らしやすい社会·生活環境 （56.8\%）

(8) 精神的に豊かな生活 (35.0\%)

(9) 物質的に豊かな生活 (30.5\%)

(10) 時間(余裕，ゆとり) (26\%)

(11) その他 $(2.2 \%)$

(12)何も連想しない $(0.2 \%)$

Q18. 地球温暖化や環境問題をどのように解決すべきだと 思われますか。（複数回答可）

(1) 科学技術の進歩 (61.3\%)

(2) 個人個人が自身の生活意識を改めること（77.7\%）

(3) 規制や環境税など政治的な決断 (39.7\%)

(4) 途上国の経済発展の規制 (8.5\%)

(5) 途上国に環境影響の少ない技術の提供 （53.4\%）

(6) 一概に言えない $(1.5 \%)$

(7) その他 $(2.9 \%)$

(8) 解決を目指さない $(0 \%)$

Q19. 地球温暖化や環境問題を克服するためなら，ご自身 の生活を変えても良いと思われますか。

(1) 皆がどうあろうとも変えてもよい（17.6\%)

(2) 皆が変えるなら変えてもよい $(13.2 \%)$

(3) ある程度なら，他者の行動に関係なく変えてもよい (56.6\%)

(4) できれば変えたくない $(4.2 \%)$

(5) 全く変えたくない $(0.5 \%)$

(6) 一概に言えない $(6.0 \%)$

Q20. 例えば原子力発電や遺伝子組久換え食品など科学技 術の導入によって，あなた自身の生命，健康，および財産 などが損なわれる可能性がある場合，どのように対応すべ きだとお考えですか。

(1) 国や地方自治体がしっかり規制すべきだ （35.2\%）

(2) 導入しようとする企業や機関が責任もって対応すべ きだ $(13.1 \%)$

(3) 個人個人が自己責任で対応すべきだ（5.1\%）

(4) 損失や危険性を最小限に抑える事を導入の前提とす べき $(19.1 \%)$

(5) 損失や危険性がまったく無いことを導入の条件とす べき $(21.2 \%)$

(6) ある程度の利益があれば損失や危険性はやむをえな い $(1.6 \%)$

(7) 一概に言えない $(2.5 \%)$

Q22. 例えば，政府や行政など社会をリードしている組織 やその中の人々を信頼していますか。 
（選択肢は本文中に記載）

Q23. 例えば, 政府や行政など社会をリードしている組織 やその中の人々として何を連想されますか。（複数回答可）
(1) 政治家(議員) (58.8\%)
(2) 政治家 (大臣，知事，市町村長） (63.2\%)
(3) 政党 (25.0\%)
(4) 官僚・公務員 (56.8\%)
(5) 大企業・産業界 (46.5\%)
(6) 学者や専門家 (有識者) (37.2\%)
(7) マスコミ $(30.3 \%)$
（8）一般の人々(民意）（7.4\%）
(9) 一概に言えない $(2.2 \%)$

Q24. あなたの生活目標として，一番近いのはどれですか。

(1) その日その日を，自由に楽しく過ごす（11.3\%)

(2)しっかりと計画をたてて，豊かな生活を築く $(24.0 \%)$

(3) 身近な人たちと，なごやかな毎日を送る (46.5\%)

(4) みんなと力を合わせて，世の中を良くする（14.2 $\%)$

Q25. 例えば原子力発電や遺伝子組み換え食品の導入など 科学技術に関わる国レベルの決定にどのように関わってい くべきだとお考えですか。（複数回答可）

(1) 常に自分の意志で関わっていきたい（17.4\%)

(2) 場合によっては，自分の意志で関わっていきたい (25.2\%)

(3) 自分の意志で関われるところから，関わっていきた い $(45.0 \%)$

(4) 自分の意志で関われるよう意欲や知識を高めていき たい $(39.7 \%)$

(5) 自分の意志で関われるように参加の手段を模索した い $(13.8 \%)$

(6) 自分の意志で関われるように参加の手段を作ってほ しい $(27.4 \%)$

（7) 自分の意志で関わるべきではない（1.5\%)

(8) 自分の意志で関わることはできない $(5.4 \%)$

(9) 自分の意志で関わることはしない $(4.2 \%)$

(10)一概に言えない $(5.1 \%)$
Q26. 例えば原子力発電所の建設など科学技術に係わる地 域レベルの決定にどのように関わっていくべきだとお考え ですか。（複数回答可）

(1) 常に自分の意志で関わっていきたい（18.7\%）

(2) 場合によっては，自分の意志で関わっていきたい (27.8\%)

(3) 自分の意志で関われるところから，関わっていきた い $(42.3 \%)$

(4) 自分の意志で関われるよう意欲や知識を高めていき たい (35.6\%)

(5) 自分の意志で関われるように参加の手段を模索した い $(17.2 \%)$

(6) 自分の意志で関われるように参加の手段を作ってほ しい (23.8\%)

(7) 自分の意志で関わるべきではない（1.3\%)

(8) 自分の意志で関わることはできない (5.1\%)

(9) 自分の意志で関わることはしない (4.7\%)

(10) 一概に言えない $(4.7 \%)$

Q27. あなたが理想とする家族の関係として，一番近いの はどれですか。

(1) 父親は主人として威厳を持ち母親は父親に心から尽 くす $(5.8 \%)$

(2) 父親も母親も自分の仕事や趣味をもち熱心に打ち込 む $(22.1 \%)$

(3) 父親は仕事に力を注ぎ，母親は任された家庭を守る $(8.5 \%)$

(4) 父親も家庭に気をつかい母親も家庭づくりに専念す る $(48.8 \%)$

(5) 一概に言えない $(10.0 \%)$

Q28. あなたが理想とする人間として，一番近いのはどれ ですか。

(1) 秩序を守る，規則正しい人間 （9.8\%）

(2) お互いの権利や生活を尊ぶ人間 $(25.2 \%)$

(3) 実社会で役立つ知識や技能を身につけた人間 $(8.2$ $\%$ )

(4) 教養があり，心が豊かな人間 $(44.5 \%)$

(5) 一概に言えない $(9.3 \%)$ 